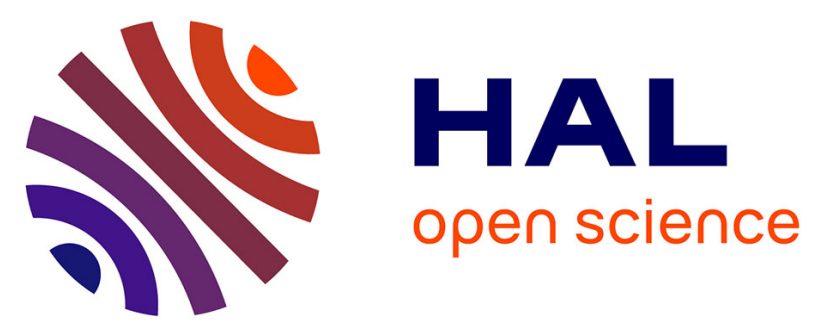

\title{
Madagascar sheds new light on the molecular systematics and biogeography of grammitid ferns: new unexpected lineages and numerous long-distance dispersal events
}

Lucie Bauret, Myriam Gaudeul, Michael A. Sundue, Barbara S. Parris, Tom A. Ranker, France Rakotondrainibe, Sabine Hennequin, Jaona Ranaivo, Marc-André Selosse, Germinal Rouhan

\section{- To cite this version:}

Lucie Bauret, Myriam Gaudeul, Michael A. Sundue, Barbara S. Parris, Tom A. Ranker, et al.. Madagascar sheds new light on the molecular systematics and biogeography of grammitid ferns: new unexpected lineages and numerous long-distance dispersal events. Molecular Phylogenetics and Evolution, 2017, 10.1016/j.ympev.2017.03.005 . hal-01490495

\section{HAL Id: hal-01490495 \\ https: / hal.sorbonne-universite.fr/hal-01490495}

Submitted on 15 Mar 2017

HAL is a multi-disciplinary open access archive for the deposit and dissemination of scientific research documents, whether they are published or not. The documents may come from teaching and research institutions in France or abroad, or from public or private research centers.
L'archive ouverte pluridisciplinaire HAL, est destinée au dépôt et à la diffusion de documents scientifiques de niveau recherche, publiés ou non, émanant des établissements d'enseignement et de recherche français ou étrangers, des laboratoires publics ou privés. 


\section{Madagascar sheds new light on the molecular systematics and biogeography of grammitid}

\section{ferns: new unexpected lineages and numerous long-distance dispersal events}

Lucie Bauret $^{\text {ab* }}{ }^{\text {, Myriam Gaudeul }}{ }^{\text {a }}$, Michael A. Sundue ${ }^{c}$, Barbara S. Parris ${ }^{\text {d }}$, Tom A. Ranker ${ }^{\text {e }}$,

France Rakotondrainibe ${ }^{\mathrm{a}}$, Sabine Hennequin ${ }^{\mathrm{b}}$, Jaona Ranaivo ${ }^{\mathrm{f}}$, Marc-André Selosse ${ }^{\mathrm{a}, \mathrm{g}}$, Germinal Rouhan $^{\text {a }}$

${ }^{a}$ Muséum national d'Histoire naturelle, Sorbonne Universités, Institut de Systématique, Evolution, Biodiversité (UMR 7205 CNRS, MNHN, UPMC, EPHE), Herbier National, 16 rue Buffon CP39, F-75005 Paris, France

${ }^{\mathrm{b}}$ Université Pierre et Marie Curie, Sorbonne Universités, Institut de Systématique, Evolution, Biodiversité (UMR 7205 CNRS, MNHN, UPMC, EPHE), 57 rue Cuvier CP48, F-75005 Paris, France

${ }^{\mathrm{c}}$ The Pringle Herbarium, Department of Plant Biology, The University of Vermont, 27 Colchester Ave., Burlington, VT 05405, USA

${ }^{\mathrm{d}}$ Fern Research Foundation, 21 James Kemp Place, Kerikeri, Bay of Islands, 0230, New Zealand ${ }^{\mathrm{e}}$ Department of Botany, University of Hawai'i at Mānoa, 3190 Maile Way, Honolulu, HI 96822,

\section{USA}

${ }^{\mathrm{f}}$ Centre National de Recherches sur l'Environnement, 34 rue Rasamimanana Fiadanana, BP 1739, 101 Antananarivo, Madagascar

${ }^{\mathrm{g}}$ Department of Plant Taxonomy and Nature Conservation, University of Gdansk, ul. Wita Stwosza 59, 80-308 Gdańsk, Poland

* Corresponding author at: Muséum national d'Histoire naturelle, Sorbonne Universités, Institut de Systématique, Evolution, Biodiversité (UMR 7205 CNRS, MNHN, UPMC, EPHE), Herbier National, 16 rue Buffon CP39, F-75005 Paris, France. E-mail address: lu.bauret@gmail.com 


\begin{abstract}
Based on a worldwide phylogenetic framework filling the taxonomic gap of Madagascar and surrounding islands of the Western Indian Ocean (WIO), we revisited the systematics of grammitid fern species (Polypodiaceae). We also investigated the biogeographic origin of the extant diversity in Madagascar and estimated the relative influence of vicariance, long-distance dispersals (LDD) and in situ diversification.
\end{abstract}

Phylogenetic inferences were based on five plastid DNA regions (atpB, rbcL, rps4-trnS, trnG-trnR, trnL-trnF) and the most comprehensive taxonomic sampling ever assembled (224 species belonging to 31 out of 33 recognized grammitids genera). 31 species from Madagascar were included representing $87 \%$ of the described diversity and $77 \%$ of the endemics. Our results confirmed a Paleotropical clade nested within an amphi-Atlantic grade. In addition, we identified three new major clades involving species currently belonging to Grammitis s.l., Ctenopterella and Enterosora. We resolved for the first time Grammitis s.s. as monophyletic, and Ctenopterella (newly tested here) and Enterosora as polyphyletic. The Neotropical genus Moranopteris was shown to also occur in Madagascar through a newly discovered species. Most importantly, we suggest a >30\% inflation of the species number in the WIO due to the hidden diversity in $>10$ cryptic lineages, best explained by high morphological homoplasy.

Molecular dating and ancestral areas reconstruction allowed identifying the Neotropics as the predominant source of LDD to the African-WIO region, with at least 12 colonization events within the last 20 Ma. Repeated eastward migrations may be explained by transoceanic westerly winds transporting the dust-like spores. Tropical Asia s.l. would also have played a (minor) role through one dispersal event to Madagascar at the end of the Oligocene. Last, within the complex Malagasy region made of a mosaic of continental and oceanic islands located close to the African continent, we showed that contrary to theoretical expectations and empirical evidence in angiosperms, Africa 
does not act as a dispersal source and Madagascar seems to have a more important influence on the regional dynamics: we observed both in situ species diversification and dispersal out of Madagascar. This influence also extends beyond the region, since one dispersal event probably originated from Madagascar and reached the Subantarctic island of Amsterdam.

Keywords: Biogeography, Ferns, Long-distance dispersal, Madagascar, Phylogeny, Western Indian Ocean 


\section{Introduction}

Madagascar is a continental island of the Western Indian Ocean (WIO) known to host an extraordinary biodiversity, with about 12000 vascular plant species (Callmander, 2011), and listed as one of the world's hotspots of biodiversity (Myers et al., 2000). Eighty-three percent of vascular plants, $52 \%$ of birds and $86 \%$ of invertebrates are endemics, and this proportion reaches $100 \%$ for terrestrial Gastropoda and non-volant Mammalia (Goodman and Benstead, 2005). However, this biological diversity is still under-documented and the evolutionary processes explaining its emergence are poorly known, since only a few phylogenetic studies are available. In particular, assessing the relative contributions of vicariance due to plate tectonics, trans-oceanic long-distance dispersal (LDD) and in situ species diversification remains a central question.

Investigating the origin and evolutionary history of Malagasy lineages is challenging because Madagascar is not strongly isolated from the East African coast, and is also surrounded by several archipelagos. Thus, Madagascar must be studied in the broader context of the WIO, involving a complex geologic history of continental and volcanic islands (Agnarsson and Kuntner, 2012). Most importantly, Madagascar was once part of the supercontinent Gondwana that began to breakup 155$118 \mathrm{Ma}$, with the separation of the America/Africa block from the Madagascar/India/Australia/Antarctica block. America and Africa split shortly after (110 Ma). Later on (118-84 Ma), India/Seychelles broke away from Madagascar before colliding with Asia 50 Ma, followed by the separation of the Seychelles Plateau (100-95 Ma; Seward et al., 2004). In addition, the WIO is characterized by two volcanic archipelagos, the Comoros and Mascarenes, which respectively emerged within the last ca. $15 \mathrm{Ma}$ (Emerick and Duncan, 1982; Nougier et al., 1986) and $8 \mathrm{Ma}$ (McDougall and Chamalaun, 1969). Whereas some studies underlined the impact of continental drift on the distribution of species occurring in Madagascar, others have more recently emphasized a greater role of LDD during the Cenozoic period (Agnarsson and Kuntner, 2012; 
Bacon et al., 2016; Buerki et al., 2013; Renner et al., 2010; Warren et al., 2010; Yoder and Nowak, 2006). At least, the role of dispersal is undisputable in the origin of lineages on the recent volcanic islands surrounding Madagascar.

In this context, ferns are a very interesting biological model to study the biogeographic origin of the Malagasy and WIO diversity. As many as 600 fern species are listed in Madagascar, among which ca. 45\% are endemic (Goodman and Benstead, 2005; Rakotondrainibe, 2003; Roux, 2009). This proportion is high, although not as high as for flowering plants and some other groups cited above, probably because ferns dust-like spores have stronger dispersal abilities that facilitate species arrival and ultimately slow down the speciation process (Smith, 1972). Spore dispersal is assumed to occur mostly through air currents, although dispersal mediated by bats (Sugita et al., 2013) or birds (Lewis et al., 2014) has been documented. This high capacity of spore movement, combined to the relatively recent origin of extant fern lineages (especially in the species-rich Polypodiales) since the Cretaceous (<150 Ma; Rothfels et al., 2015; Schuettpelz and Pryer, 2009), suggests a major influence of LDD compared to Gondwanan vicariance in the origin of the African-WIO groups. In particular, connections between the Neotropics and Madagascar were previously highlighted based either on floristic affinities (Moran and Smith, 2001) or on molecular phylogenetic analyses. Among the latter studies, LDD between the two areas were hypothesized for numerous Elaphoglossum lineages (Rouhan et al., 2004; Vasco et al., 2009), and in the genera Lomariopsis (Rouhan et al., 2007), Stenogrammitis (as Lellingeria in Labiak et al., 2010), Leucotrichum (Rouhan et al., 2012) and other Polypodiaceae (Janssen et al., 2007). Transatlantic LDD was also inferred based on dated phylogenies in Alsophila (Janssen et al., 2008) and Parapolystichum (Labiak et al., 2014). Claims for Asiatic origins have also been documented, highlighting dispersal routes from Asia e.g. in the genera Pteris (Chao et al., 2014), Nephrolepis (Hennequin et al., 2010), and Deparia (Kuo et al., 2016). At a more restricted scale, data on ferns are almost completely lacking within the African-WIO region, although a few insights from Platycerium (Kreier and 
Schneider, 2006) and Alsophila (Janssen et al., 2008) might support continental Africa as a source of dispersal to Madagascar. This trend, implying migration across the Mozambique Channel, is strongly supported in other plant groups (Agnarsson and Kuntner, 2012).

Our study focused on grammitid ferns that had long been considered as a family, 'Grammitidaceae', until they were shown to form a clade nested within the larger Polypodiaceae family using molecular data (Ranker et al., 2004; Schneider et al., 2004; Sundue et al., 2014). Comprising around 1500 species, Polypodiaceae is the second largest family of ferns. The estimated 900 species of grammitid ferns (Perrie and Parris, 2012) belong to 33 genera, many of which were described in the last decade based on molecular phylogenetic studies that revealed extensive polyphyly as a recurrent issue resulting from morphological homoplasy (Ranker et al., 2004; Sundue et al., 2010a). Grammitid ferns are mostly found as epiphytes in tropical montane forests, and distributed in two main phytogeographic zones (Parris 2003): i) around 400 species in the Neotropics, tropical Africa, and the WIO (including Madagascar, Mascarenes, Comoros and Seychelles); and ii) around 500 species in tropical Asia s.1., including Malesia and the Pacific Ocean islands. The Neotropics and the WIO were grouped in the same phytogeographic zone because they share several taxa: the genera Alansmia, Ceradenia, Cochlidium, Enterosora, Grammitis, Leucotrichum, Melpomene, Stenogrammitis, and Zygophlebia, and even some species (Alansmia elastica, Cochlidium serrulatum and Melpomene flabelliformis). In contrast, only a few taxa are known to be shared by the two phytogeographic zones: i) Ctenopterella is mainly distributed in Malesia and the SouthPacific Ocean islands, but also in the WIO although its monophyly has never been tested; ii) Stenogrammitis is mainly Neotropical but also distributed in Africa, the WIO, Hawaii and the South-Pacific Ocean islands. iii) Notogrammitis has a circumaustral distribution, from Australia and New Zealand to South Africa and South America. 
A recent phylogenetic and biogeographic study showed that grammitids evolved from a Neotropical ancestor between the end of the Eocene and beginning of the Paleocene (45-37 Ma; Sundue et al., 2014). In agreement with the distribution patterns and delimitation of the two phytogeographic zones, the inferred phylogeny exhibited a clear geographic pattern: a single clade from tropical Asia s.l. (comprising Australia and Melanesia) was nested in a Neotropical grade, which also included the WIO species. This result was explained by one LDD from the Neotropics to tropical Asia s.l. at the end of the Paleocene, and repeated LDD from the Neotropics to the WIO since molecular dating suggested relatively recent diversification and allowed excluding vicariance hypotheses linked to Gondwana breakup. However, the sampling of Sundue et al. (2014) included only eight species occurring in the WIO, so that many questions remain about the systematics and biogeography of grammitid species in this area.

For the WIO and Africa, Roux (2009) listed 51 species of grammitid ferns belonging to 9 genera, and in particular 31 species in Madagascar including 13 endemics (Table 1; Fig. 1). However, taking into account several taxa awaiting description based on morphological evidence, the actual diversity could reach $>40$ species in Madagascar alone. In addition, generic delimitations have to be revised for some genera already identified as non-monophyletic at the worldwide scale (especially Grammitis and Zygophlebia), and may also have to be for some others (in particular Ctenopterella, which is shared between Tropical Asia s.l. and the WIO; Table 1).

Based on an extended sampling and using phylogenetic inference, molecular dating and ancestral area estimation, we aim at improving the systematics of the Malagasy and other WIO grammitids, better understanding their biogeographic history, and shedding light on the evolutionary mechanisms that led to their emergence. More specifically, our goals are: i) to further test the monophyly of grammitid genera, particularly those diversified in the WIO, namely Grammitis, Zygophlebia and for the first time Ctenopterella; ii) more broadly, to improve the systematics of 
grammitid ferns by delimiting species as monophyletic groups; iii) to test the global biogeographic scenario proposed by Sundue et al. (2014); iv) to infer the biogeographic origin of the Malagasy and other WIO species (i.e., did they emerge after dispersal events from the Neotropics only, as suggested by Sundue et al. (2014)? How many such events explain the extant diversity in the area?); iv) to assess to what extent dispersal occurred and the predominant migration routes at the regional scale, in the WIO; and v) to check whether diversification occurred within the WIO.

\section{Materials and methods}

\subsection{Taxonomic sampling}

The sampling was composed of two parts: the first one, based on the worldwide grammitid phylogeny of Sundue et al. (2014), included 199 samples representing 180 grammitid species and provided a global framework. The second one was focused primarily on the WIO and Africa, and even more specifically on Madagascar: 193 new samples represented 61 species (Appendix 1). In total, the ingroup comprised 396 samples representing 224 species, including 36 species from Africa and WIO islands, of which 31 occur in Madagascar (taking into account a few undescribed species), and 12 of which are endemic (representing $87 \%$ of the described species, and ca. $77 \%$ of the described endemics). A total of 31 out of 33 recognized grammitid genera were represented (Archigrammitis Parris and Luisma M.T.Murillo \& A.R.Sm. were lacking) and one type species (Tomophyllum subsecundodissectum) was newly sampled, for a total of 21 type species (Appendix 1). Five outgroups were added, belonging to four other Polypodiaceae genera that belong to the sister clade of grammitids (Sundue et al., 2015): Microgramma C.Presl, Niphidium J.Sm., Polypodium L. and Serpocaulon A.R.Sm. Voucher information is listed in Appendix 1.

\subsection{DNA sequencing}


Total genomic DNA was extracted using the Qiagen DNeasy Plant Mini Kit (Valencia, California, USA) either from silica-dried leaves whenever available, or from herbarium specimens. The manufacturer's protocol was followed but slightly modified for herbarium samples, adding $30 \mu \mathrm{L}$ proteinase $\mathrm{K}(20 \mathrm{mg} / \mathrm{mL})$ and $30 \mu \mathrm{L}$ beta-mercaptoethanol for the initial lysis step, which was carried out at $42{ }^{\circ} \mathrm{C}$ during $24 \mathrm{hrs}$ on a tipping plate.

The polymerase chain reaction (PCR) was used to amplify five plastid DNA regions: the two coding genes $a t p B$ and $r b c L$, and the three non-coding intergenic spacers: rps4-trnS, $\operatorname{trn} G$-trnR and trnL-trnF. PCR were carried out in a $25 \mu \mathrm{L}$ volume containing 1x PCR buffer, $2.5 \mathrm{mM} \mathrm{MgCl}_{2}, 250$ $\mu \mathrm{M}$ of each dNTP, $1 \mathrm{M}$ betaine, $0.4 \mu \mathrm{M}$ of each primer, $0.75 \mathrm{U}$ Taq polymerase (Taq CORE kit; MP Biomedicals, Illkirch, France), and $0.75 \mu \mathrm{L}$ of template DNA. Primer sequences and thermal cycling conditions are reported in Table 2. The resulting PCR products were checked on a $1 \%$ agarose gel and sequenced in both directions at the Centre National de Séquençage (Evry, France), using the amplification primers and additional, internal primers for atpB, $r b c L$ and $\operatorname{trn} G$-trnR (Table 2). Forward and reverse DNA strands were assembled in Sequencher 4.9 (GeneCodes Corporation, Ann Arbor, Michigan, USA). The newly obtained consensus sequences were submitted to GenBank (accession numbers listed in Appendix 1).

\subsection{Phylogenetic analyses}

The sequences were aligned with the MAFFT plugin (Katoh and Toh, 2010) in Jalview 2.8.2

(Waterhouse et al., 2009) using the default parameters. The alignments were then checked and revised manually when necessary. For each DNA region, the most suitable model of nucleotide substitution was determined with MrModelTest 2.3 (Nylander, 2004), following the Akaike Information Criterion. A data matrix was then built by concatenation of all five regions using Sequence Matrix 1.7.8 (Vaidya et al., 2011), each DNA region constituting a distinct partition in the final dataset. 
Phylogenetic trees were inferred based on two probabilistic methods: Maximum Likelihood (ML) and Bayesian Inference (BI), as respectively implemented in RAxML-HPC2 8.2.6 (Stamatakis, 2014) and MrBayes 3.2.3 (Ronquist et al., 2012). Gaps were treated as missing data and analyses were performed on the CIPRES science gateway (Miller et al., 2010). Parameters for the RAxML analysis were determined on the CIPRES interface. We used the GTRGAMMA+I model of nucleotide substitution for each partition, performed 1000 rapid bootstrap (BS) replicates and searched for the best-scoring ML tree. In MrBayes, we conducted two independent but parallel analyses with four chains each (one cold and three incrementally heated at a temperature of 0.1 ). The BI analyses were run for 15 million generations each, sampled every 1500 generations, and performed with the GTR $+\mathrm{I}+\Gamma$ model of nucleotide substitution for each partition and parameters unlinked. Tracer 1.6.0 (Rambaut and Drummond, 2013) was used to check that effective sample sizes were higher than recommended (>200) and that the two runs had converged to the stationary distribution. The $25 \%$ initial trees were discarded as burn-in, the post-burn-in trees (15000 total trees) were pooled and a 50\% majority-rule consensus was computed with average branch lengths and posterior probability (PP) estimates for all nodes. This tree and the best ML tree were visualised with FigTree 1.4.2 (Rambaut, 2014).

\subsection{Divergence time estimation}

Divergence time estimation was performed on the CIPRES science gateway using BEAST 1.8.0 (Drummond et al., 2012). Our biogeographic analyses were performed at the species level and focused on Madagascar. Therefore, given that the BEAST outputs were used as inputs for the estimation of ancestral areas, we reduced our ingroup sampling to 149 samples representing 139 species for the dating analysis. For genera that included Malagasy species, we kept one sample per species that was retrieved as monophyletic and as many samples as retrieved lineages when species were poly- or paraphyletic. For genera without any Malagasy species, we retained at least two samples of two distinct species including the type species of the genus whenever available, and the 
species that was recovered as the most early-diverging lineage (in order not to underestimate the diversification date of the genus). For genera with no resolution on the crown node, we kept all the sampled species branched on the polytomous node.

Partitions and models of nucleotide substitution were the same as for the BI. An uncorrelated lognormal relaxed clock was used, with a Yule tree prior (Gernhard, 2008) and a random starting tree. Based on a large-scale, fossil-based study on leptosporangiate ferns (Schuettpelz and Pryer, 2009), we used four secondary calibration points corresponding to four well-supported clades within the Polypodiaceae (nodes 367, 368, 378, 382 in Schuettpelz and Pryer 2009; figured as black squares on Fig. 4) that were also used by Sundue et al. (2014). These points were modelled by normal distribution priors on crown nodes, with $10 \%$ standard deviation (S.D.) in all cases: (1) the age of the grammitid clade was set to $31.2 \mathrm{Ma}$ (S.D.=3.1); (2) the age of the Neotropical clade including Mycopteris-Stenogrammitis was set to 23.3 Ma (S.D = 2.3); (3) the age of the clade including the Paleotropical clade plus Moranopteris, was set to $23.4 \mathrm{Ma}$ (S.D. = 2.3); and (4) the diversification of the genus Serpocaulon, in the outgroup, was dated to $15.5 \mathrm{Ma}$ (S.D. = 1.5). The prior for ucld.mean was defined by continuous-time Markov chain (CTMC) Rate Reference, as advised when no prior knowledge is available (Ferreira and Suchard, 2008). Two analyses of 20 million generations each were performed with tree and parameters sampling every 2000 generations. Tracer 1.6.0 was used to define burn-in length and the first 1000 trees (10\%) were discarded for each run. We used LogCombiner v1.8.0 to combine results from the two runs and TreeAnnotator v1.8.0 (Drummond et al. 2012) to compute the maximum clade credibility tree. FigTree 1.4.2 (Rambaut, 2014) was used to visualize the maximum clade credibility tree and the associated chronogram.

\subsection{Ancestral areas estimation}

We used both the statistical Dispersal-Vicariance Analysis S-DIVA (Yu et al., 2010) and the BayesLagrange S-DEC (Beaulieu et al., 2013) models implemented in the RASP software (Yu et al., 
2015) to estimate ancestral ranges at all nodes. Nine biogeographic regions were defined (see Fig.

2): (A) Madagascar; (B) Mascarenes (including Réunion, Mauritius, and Rodrigues; but no grammitid species is known from Rodrigues), Comoros, and Seychelles (regions A and B together form the WIO); (C) Continental Africa except North Africa; (D) Neotropics; (E) Tropical Asia s.1. (India to South-East Asia and Japan, North Australia and Melanesia except Fiji); (F) Other Pacific Ocean islands (Fiji, Micronesia, French Polynesia, Hawaiian Islands); (G) Temperate circumaustral region, south of $28^{\circ} \mathrm{S}$ latitude; (H) South Atlantic Islands (Saint Helena); and (I) North America. Geographic distributions were coded for all species, based on Sundue et al. (2014), and on herbarium specimens (mostly from the Paris Herbarium) and personal observations for all other samples. The taxonomic identification of all herbarium specimens was checked. We considered polyphyletic species as distinct lineages and coded as many distinct distributions as retrieved lineages. The maximal number of ancestral areas was set to two and, owing to the high winddispersal ability of fern spores over long distances, we considered that dispersal probability was not correlated to geographic distance. The frequencies of an ancestral range at a node were averaged over 100 random, post burn-in trees taken from the BEAST output. The condensed tree was the maximum clade credibility tree estimated in BEAST.

\section{Results}

\subsection{Phylogenetic analyses}

Our combined DNA sequence matrix of the five plastid regions was composed of 401 specimens and 5593 base pairs. Table 3 reports the percentage of samples successfully sequenced and other statistics, for each DNA region and the combined alignment. The phylogenetic hypotheses produced by the ML analysis and BI resulted in very similar topologies, with a few minor, not statistically supported differences. Consequently, only the BI topology is summarized in Fig. 2 (see Appendix 2 for the full tree with all terminals). 
Both the ML analysis and BI supported grammitid ferns as a strongly-supported clade $(\mathrm{BS}=100$; $\mathrm{PP}=1$; Fig. 2). The resulting phylogeny was almost fully resolved at the species level. Most nodes were strongly supported, especially those supporting genera (BS $\geq 95$ and/or $P P \geq 0.95$; Fig. 2), although more moderate support values were retrieved for the backbone nodes and some nodes within clade-1 (Fig. 2). The inferred topology almost fully agreed with the most recent phylogenetic study on the group (Sundue et al., 2014), with two notable exceptions: we recovered Grammitis s.s. as monophyletic $(\mathrm{BS}=100 ; \mathrm{PP}=1)$, and three new clades were supported (highlighted as grey-filled triangles, Fig. 2) involving species currently classified in Grammitis, Ctenopterella and Enterosora (as detailed later).

The phylogeny was geographically structured, with a Paleotropical clade $(\mathrm{BS}=78 ; \mathrm{PP}=0.86)$ nested within a large grade (Fig. 2). The Paleotropical clade included 15 genera mostly distributed in tropical Asia s.l. and the Pacific Ocean islands. Notably, the Paleotropical clade also comprised eight species from the WIO and Africa, belonging to Ctenopterella and Grammitis and all together forming clade-3 (BS=100; $\mathrm{PP}=1 ; \mathrm{Fig}$. 2). This clade is a newly recovered one for grammitids. The relationships between clade-3, Chrysogrammitis, and the rest of the Paleotropical clade were not resolved.

The rest of the tree consisted of a large grade, hereafter called amphi-Atlantic grade. It included 17 genera showing either an exclusively Neotropical distribution for six genera, or a distribution on both sides of the Atlantic Ocean (including Africa and the WIO) for 10 genera (with the exceptions of Stenogrammitis and Grammitis s.s., which include a few additional species from the Pacific Ocean islands, tropical Asia s.l. or the circumaustral region; and Adenophorus restricted to Hawaii; Fig. 2).

Out of the 31 genera that we sampled, monophyly could not be assessed for Acrosorus and Lomaphlebia (represented by only one species each). Twenty-two genera were recovered as monophyletic, including Moranopteris that was exclusively described from the Neotropics to date 
and that was also represented in this study by an undescribed, endemic species to Madagascar (Moranopteris sp. 1). By contrast, seven genera were not recovered as monophyletic: Ceradenia, Ctenopterella, Enterosora, Grammitis, Oreogrammitis, Radiogrammitis and Zygophlebia (indicated in bold, Fig. 2). In particular, Grammitis, Ctenopterella and Enterosora were retrieved as highly polyphyletic: Grammitis was retrieved in the clade-1 of the amphi-Atlantic grade (as Grammitis s.s.), but also as four distinct lineages within the Paleotropical clade (two lineages in clade-3, one clade sister-group to Notogrammitis, and G. stenophylla as sister lineage to the AcrosorusCtenopterella denticulata clade; Figs. 2 \& 3). Ctenopterella species formed three distinct lineages within the Paleotropical clade: C. denticulata was included in the clade Acrosorus-Grammitis stenophylla clade, C. lasiostipes and two other undescribed species were sister-group to GrammitisNotogrammitis, and two species were included in clade-3; Figs. 2 \& 3). Enterosora was retrieved as four lineages belonging to the amphi-Atlantic grade: two species were sister-group to Adenophorus in clade-1 and, in clade-2, two distinct lineages were nested within Zygophlebia (counting four and one species, respectively) and one species within Ceradenia (Fig. 3).

Our molecular sampling included multiple individuals per species, especially for those from the WIO, and also allowed the identification of several cases of polyphyly at the species level. Twentyeight species were thus recovered as non-monophyletic (Appendix 2). They belonged to 15 genera and included 12 species from the WIO and Africa (Table 4). These 12 non-monophyletic species were mostly found in Grammitis, with four non-monophyletic species in Grammitis s.s. (highlighted in distinct colors; Fig. 3, clade-1; Table 4) and six non-monophyletic species which could be classified in one to several new genera in order to accommodate their placement in clade-3 (Fig. 3; Table 4).

\subsection{Divergence time and ancestral areas estimations}




\subsubsection{Divergence time estimation}

Molecular dating showed that grammitid ferns diverged from other Polypodiaceae about 39.3 Ma (stem age; 95\% Highest Posterior Density (HPD) interval: 31.2-50.6) and started to diversify at least 34.1 Ma (crown age; 95\% HPD: 28.3-40.2) at the end of the Eocene (Fig. 4A). The Paleotropical clade was dated to 24.9 Ma for the stem age (95\% HPD: 19.6-28.1; Fig. 4B).

Divergence dates (stem ages) of generic lineages ranged between 13.1 Ma (divergence between Acrosorus and Ctenopterella denticulata; 95\% HPD: 9.0-18.1; Fig. 4B) and 32.1 Ma (divergence between Terpsichore and its sister-clade; 95\% HPD: 26.5-38.7; Fig. 4A), while their diversification (crown) ages ranged between 2.0 and 14.6 Ma for Xiphopterella and Ascogrammitis respectively (Fig. 4B). In fact, diversification could also have occurred earlier: several new genera will have to be newly described based on this study (see Table 3 and Discussion) and as a result, the potential genus corresponding to clade- $\mathrm{V}$ would have started to diversify $21.1 \mathrm{Ma}$.

\subsubsection{Ancestral areas estimation}

S-DIVA and S-DEC analyses produced very similar results. When they differed, S-DEC inferred slightly broader ancestral areas (i.e., including an additional region, but with a low probability), but the areas inferred by S-DIVA were also always the most probable ones inferred by S-DEC (results not shown). The only notable difference was an ancestral area covering both Madagascar and the Neotropics for the crown node of Stenogrammitis and its next outer node by S-DEC, vs. Madagascar only by S-DIVA (Fig. 4B).

Grammitid ferns originated and diversified in the Neotropics (Fig. 4A) and a Neotropical origin was also inferred for all the generic lineages of the amphi-Atlantic grade, with two exceptions: the ancestral area of Adenophorus was inferred in the Neotropics and the Pacific Ocean islands, while Stenogrammitis would have originated in the Neotropics and Madagascar. 
The Paleotropical clade originated in tropical Asia s.l. and the Neotropics (Fig. 4B). Within this clade, all genera have an exclusively tropical Asian origin, except Notogrammitis (for which the circumaustral area was also inferred) and clade- $\mathrm{V}$ if considered as a new genus (for which Madagascar was also inferred).

\subsubsection{Focus on Madagascar, surrounding islands and Africa}

The lineages occurring in this region were dispersed throughout the phylogeny. They originated by 13 LDD events dated from the end of the Oligocene or more recently (indicated by black arrows on branches; Fig. 4): 12 from the Neotropics and one from tropical Asia s.1., leading to clade-V. However, this latter event was not statistically supported since the node grouping the African-WIO clade-V with the rest of the Paleotropical clade (excluding the Asian genus Chrysogrammitis) had $\mathrm{PP}=0.45$. Five LDD were inferred to Madagascar (black arrows for LDD-3, LDD-5, LDD-10, LDD-12 and LDD-13; Fig. 4). These events resulted in three species endemic to Madagascar: Grammitis ebenina-Rouhan1180 (LDD-3), Leucotrichum madagascariense (LDD-5) and Moranopteris sp. 1 (LDD-12). The two other dispersal events to Madagascar were at the origin of the genus Stenogrammitis (LDD-10) and of clade-V (LDD-13 from Asia). One LDD only reached Africa (LDD-8). Seven other LDD gave rise to lineages distributed in several areas, with no possibility to infer whether one or several dispersal events occurred, and which area(s) was(were) colonized at first (LDD-1, 2, 4, 6, 7, 9 and 11). Only one transatlantic LDD from Madagascar back to the Neotropics was suggested, within the genus Stenogrammitis.

At a regional scale, several dispersal events were also inferred in all directions between Madagascar, Africa and the neighbouring islands, but most of them originated from Madagascar to give rise to Grammitis melanoloma endemic to Réunion, and for others to expand their original ranges (Grammitis cryptophlebia, Zygophlebia devoluta-Rouhan1379, Zygophlebia torulosa, Enterosora barbatula-Rouhan1186, Stenogrammitis oosora, Grammitis synsora, Grammitis pygmaea, Ctenopterella zenkeri and Ctenopterella parvula). In two cases, dispersal originated in 
other WIO islands: Ceradenia sechellarum dispersed to Africa, and Ceradenia comorensis to Madagascar. Last, only one dispersal was inferred from Africa towards Madagascar and the other WIO islands, which gave rise to clade-III (Zygophlebia-Enterosora; Fig. 4).

The analysis suggested that out of the 13 LDD that gave rise to lineages of the WIO and Africa, five were followed by species diversifications in the region (clades I to V, Fig. 4).

\section{Discussion}

Our phylogenetic analyses included $25 \%$ of all grammitid species and especially filled major gaps in the Malagasy and other WIO taxa (e.g., $87 \%$ of the described Malagasy diversity and $77 \%$ of the known endemics are now included vs. $22 \%$ and $0 \%$, respectively in Sundue et al. 2014). This allowed improving our understanding of both the worldwide systematics and the biogeographic history of the group, as hereafter discussed.

\subsection{Systematic implications}

Our results generally supported those previously obtained with a more limited sampling (Sundue et al., 2014): grammitid ferns formed a strongly supported clade, and the same global topology was recovered although support values of deeper nodes were more moderate. In addition, 22 genera were confirmed as monophyletic and four as polyphyletic (Grammitis, Oreogrammitis, Radiogrammitis and Zygophlebia; the assessment was not possible for Lomaphlebia and Acrosorus, represented by only one species each, and for Luisma and Archigrammitis still to be sampled; Fig. 2).

Besides these, our results revealed six new major findings: i) Grammitis s.s. was resolved as monophyletic; ii) all other species of Grammitis s.l. were retrieved across four lineages, reinforcing the polyphyly of this genus; iii) for the first time, Ctenopterella (newly tested here) and Enterosora were recovered as polyphyletic; iv) three new major clades were supported (grey-filled triangles 1 , 2, and 3, in Fig. 2), involving species currently classified in Grammitis s.l., Ctenopterella and 
Enterosora; v) three new species, suspected based on morphological evidence, were confirmed as distinct molecular lineages and will be described elsewhere (Moranopteris sp. 1 as endemic to Madagascar, whereas the genus was known only from the Neotropics to date; Stenogrammitis sp. 1 as endemic to Amsterdam Island, which is the new southernmost occurrence for the genus; and Zygophlebia sp. 1 as endemic to the Comoros); and vi) a high level of cryptic species was suggested. Some of these findings being related to each other, they are hereafter discussed by genus or new major clade.

\subsubsection{Grammitis s.s. is monophyletic}

Grammitis s.s. was newly resolved as monophyletic and sister-clade to Cochlidium (Fig. 2), whereas it was previously interpreted as paraphyletic with respect to Cochlidium (Sundue et al., 2014). Our result is in agreement with morphological observations, which suggested that all the ca. 20 species showing distinct, blackish sclerotic lamina margins (e.g. G. copelandii; Fig. 1E) were close relatives (Parris, 2007). All such species are indeed placed within Grammitis s.s. in our molecular phylogeny, and we also anticipate that the type species of the genus (G. marginella, not included here) belongs to this group. However, G. cryptophlebia and G. coriaceifolia ined. are also both nested within Grammitis s.s. based on molecular data, although their laminae do not exhibit blackish margins (Fig. 3, clade-1). It suggests that this character was lost at least once during the evolution of the clade. Consequently, the blackish sclerotic margin adds to the long list of homoplastic morphological characters in the evolution of grammitids (Ranker et al., 2004), which resulted in the recent description of many genera.

4.1.2. Grammitis s.l. and Ctenopterella are highly polyphyletic, and lead to the identification of two new major clades.

Apart from the Grammitis s.s. clade, other Grammitis species were retrieved in four lineages (Fig.

2) that are consequently in need of new generic concepts. These phylogenetic placements were 
described previously for G. stenophylla (sister lineage to Acrosorus and Ctenopterella denticulata), and for the three-species clade sister to Notogrammitis (Perrie and Parris, 2012; Sundue et al., 2014). In addition, we identified two new lineages nested within clade-3 (Fig. 2).

The latter clade-3 is new for the grammitid phylogeny. Exclusively composed of African and WIO species, it was unexpected due to its singular placement within the large Paleotropical clade otherwise only composed of Asian and Oceanian taxa, and due to its grouping of six species of Grammitis with two species of Ctenopterella (Figs. 2 \& 3). Laminar dissection was commonly used to distinguish Grammitis (simple, undivided laminae; Fig. 1E) from Ctenopterella (pinnatisect laminae; Fig. 1C) but the grouping of species from the two genera, in clade-3, supports leaf dissection as homoplastic as evidenced within other grammitid genera like Ceradenia (Ranker et al., 2004). This explains why the modern generic classification of grammitids is rather based on characters of the rhizomes, rhizome scales and frond hairs (Parris, 2009; Sundue, 2010; Sundue et al., 2010a). However, many of these morphological characters are variable among the species clustered in clade-3 (e.g., rhizome symmetry is either dorsiventral or radial, rhizomes scales are concolorous or bicolor, and clathrate or not). Clade-3 could nevertheless be supported by the presence of hydathodes, hypothesizing one reversion in the anhydathodous G. obtusa (Fig. 3). This clade could be treated as one or several new genera distinct from Grammitis, which should ultimately be restricted to Grammitis s.s. Another possibility would be to accommodate the six species of Grammitis of clade-3 in an expanded concept of Ctenopterella. However, the placement of Ctenopterella in the whole tree is uncertain because the type species of the genus $(C$. blechnoides) has never been sampled and moreover, we recovered the three other sampled species of Ctenopterella as another distinct, new clade of the grammitid phylogeny (Fig. 2).

Of this new Ctenopterella lineage, retrieved as sister to the clade formed by Notogrammitis and three species of Grammitis (Fig. 2), two species are endemic to New Caledonia (C. lasiostipes and Ctenopterella sp. 1) and the third, Ctenopterella sp. 2, occurs in eastern Papua New Guinea, Solomon Islands and Vanuatu (Parris unpubl.; Appendix 2). We speculate that most, if not all other 
species from Oceania and South-eastern Asia (including the type species C. blechnoides) could belong here, i.e., 16 out of the ca. 21 species in the genus (Parris, 2012, 2009). In contrast, the four Ctenopterella species from Africa and the WIO (Parris, 2012) likely all cluster in clade-3 (as observed for the two species included here, C. zenkeri and C. parvula).

\subsubsection{Enterosora is highly polyphyletic, notably revealing a new major grammitid clade} Enterosora was here recovered as polyphyletic for the first time (Fig. 2). Although the genus was previously hypothesized as paraphyletic with respect to Zygophlebia (Sundue et al., 2010a), it was recently supported as monophyletic (Sundue et al., 2014). Our extended sampling included nine out of ca. 17 Zygophlebia species plus seven out of 11 Enterosora species, and led to two findings. First, the close relationship between these two genera was confirmed, two lineages of Enterosora being nested within Zygophlebia (Fig. 3, clade-2). The lack of morphological apomorphy supporting Enterosora (Ranker et al., 2004; Sundue, 2010) argues for including the five concerned species (E. enterosoides, E. trifurcata, E. trichosora, E. percrassa and E. barbatula) into Zygophlebia (the additional segregate lineage of E. barbatula from Réunion Island, retrieved within Ceradenia, is discussed in the next section, 4.1.4).

Second, the two species E. parietina and E. sprucei formed a new clade, placed as sister-group to Adenophorus (Figs. $2 \& 3$, clade-1). This grouping is meaningful since E. parietina and E. sprucei are morphologically most closely related to each other within the genus. It is also in agreement with Bishop and Smith (1992), who underlined that the affinity of E. sprucei (as E. gilpinae) and E. parietina to other species of Enterosora was not obvious, especially considering unique characters like medial soral placement and the number of annulus cells in the sporangia. All these characters should help to define a new genus accommodating this new clade. The type species of the genus, $E$. campbellii, has not been sampled yet, however we expect it to reside within clade-2 based on its assemblage of morphological characters. Within the new clade, E. parietina and E. sprucei were not monophyletic with respect to each other, in agreement with Bishop and Smith (1992) who regarded 
them as conspecific in the Neotropics (as E. parietina). In fact, our results even support recognition of only one species on both sides of the Atlantic Ocean, as suggested by Parris $(2002,2005)$ and contrary to Bishop and Smith (1992) who distinguished E. parietina in the Neotropics from $E$. gilpinae in Africa and Madagascar.

\subsubsection{High level of cryptic species as revealed by a dense sampling on Madagascar} Our sampling, especially focused on Madagascar and other WIO islands and Africa, included at least two individuals from each of 30 species from this geographical region. This allowed assessment of monophyly at the species level. Based on our molecular data, a total of 12 species were revealed as non-monophyletic, although we could not identify morphological characters to differentiate the distinct lineages recovered for each nominal species (Table 4, Appendix 2). Therefore, nine of these species are best interpreted as cryptic species (Bickford et al., 2007). The three remaining ones (Stenogrammitis oosora, Stenogrammitis sp. 1, and Enterosora sprucei) deserve further investigation since they could actually turn out to represent a single species each (see Table 4). In three cases of polyphyly (Grammitis ebenina (Fig. 3, clade-1), Grammitis kyimbilensis (Fig. 3, clade-1) and Enterosora barbatula (Fig. 3, clade-2), the segregate lineages occurred in disjunct geographic areas. This provides an additional line of evidence to describe new species (respectively, two new species for Madagascar and one for Madagascar/Africa) that would accommodate the segregate, allopatric species with monophyly (Table 4). By contrast, for the six other cryptic species, only an in-depth study of integrative taxonomy combining molecular data, morphology, anatomy, cytometry and cytology might help to identify discriminating characters. Given that most grammitid ferns are epiphytes, a possibility of differential host-plant specificity should also be explored.

We do not know the evolutionary processes underlying cryptic speciation, but the apparent morphological similarity must be either a plesiomorphy due to shared ancestry (morphological 
stasis), or a homoplastic result of parallel or convergent evolution. Morphological stasis is rather expected to result from non-ecological vicariant speciation, e.g., when the topography is complex and populations are isolated (Britton et al., 2014). In contrast, parallel or convergent evolution usually suggests the influence of selection, e.g., to adapt to extreme environmental conditions (Bickford et al., 2007) such as high elevations for many grammitid ferns (Parris, 2009; Sylvester et al., 2014). We tend to favour the latter mechanism given the high dispersal capacities of ferns and the well-known homoplastic nature of several morphological traits in this group (Ranker et al., 2004). Hybridization might also be at the origin of some cryptic species (Mallet, 2007) and is thought to be especially frequent in ferns compared to angiosperms (Barrington et al., 1989; Haufler, 2008). Hybrids are often postulated based on morphological intermediacy between the two putative parents, but they sometimes retain the overall morphology of only one parent. In such a case, the comparison of plastid- and nuclear-based phylogenetic analyses may eventually provide evidence of such reticulate evolution, and explain the incongruence between morphological and molecular plastid data.

Our results showed that the identification of morphologically cryptic lineages increased the number of sampled species from 36 to $>50$ in the African-WIO region (some cryptic species have to be confirmed, and their exact number cannot be firmly established). Whatever the evolutionary origins of the cryptic species, failure to distinguish them greatly underestimates species richness (Gill et al., 2016), and consequently the impact of habitat destruction that is already a very serious threat in the Malagasy region (Harper et al., 2007). The inclusion of several samples per a priori delimited species is therefore crucial in a conservation perspective, to uncover the possible hidden but threatened Malagasy diversity.

Finally, taking into account all our phylogenetic findings, we suggest that the African-WIO region harbours $>68$ grammitid species ( $>50$ analyzed here, plus 18 non-sampled species) instead of the 51 previously listed (Roux 2009); that is, we document a >30\% increase in the species richness of the 
region. Although some taxa are still missing and the extinction of some lineages may bias the inferences as in all biogeographic studies, our extended sampling provides valuable insights into the biogeographic events and evolutionary processes underlying the emergence of the species in the region.

\subsection{Biogeographic history of grammitid ferns, and origins of the African-WIO species}

\subsubsection{At the worldwide scale: a Neotropical origin, followed by numerous LDD events} At the global scale, as in Sundue et al. (2014), our results supported the Neotropical origin of grammitids and the divergence and start of diversification of the group were dated to the Eocene and early Oligocene (39 and $34 \mathrm{Ma}$, respectively). This relatively recent timing confirms that dispersal, rather than vicariance linked to continental fragmentation, explains species distribution patterns. The high dispersal ability of dust-like spores has been previously invoked to explain LDD in fern lineages of diverse ages and in different areas (e.g., Chao et al., 2014; Chen et al., 2015; Hennequin et al., 2010; Labiak et al., 2014, 2010; Le Péchon et al., 2016; Lu et al., 2012; Wang et al., 2012; Wei et al., 2015). In addition, epiphytism with occurrence of long-lived and slow growing gametophytes, as observed in grammitids (Parris, 1990; Stokey et al., 1958), may allow to delay sexual reproduction until a second gametophyte germinates nearby and confer an additional advantage for successful colonization (Dassler and Farrar, 2001; Moran and Smith, 2001; Sessa et al., 2016).

4.2.2. Origin of the African-WIO grammitids: a clearly predominant role of the Neotropics, with one possible migration from Tropical Asia s.l.

Based on the phylogenetic pattern composed of 'a monophyletic tropical Asian clade nested within a primarily Neotropical and African grade', Sundue et al. (2014) inferred the expansion and diversification of grammitids throughout the tropics. From the Neotropics, they inferred at least six 
dispersal events to Madagascar, two to the Hawaiian Islands in the Pacific, and only one to tropical Asia s.l. where the group underwent a striking species diversification (referred to as the Paleotropical clade, emerging in the late Oligocene $25 \mathrm{Ma}$ ). From tropical Asia s.1., they showed that the group further dispersed towards the Hawaiian Islands on the one hand, and to the circumaustral region on the other hand.

In contrast to those previous findings, we recovered the existence of an African-WIO clade nested within the Paleotropical clade, and composed of species sampled for the first time (clade-V, Fig. 4). This suggests the occurrence of a newly inferred dispersal from Tropical Asia s.l. to the AfricanWIO region (see map, Fig. 4), which would be the oldest LDD event to this region observed in grammitids, at the end of the Oligocene. However, this inference remains to be confirmed since the branching pattern of the African-WIO clade with the rest of the Paleotropical clade was not wellsupported statistically. Therefore, we cannot fully exclude that dispersal actually occurred from the Neotropics to Africa-WIO, and either later on from Africa-WIO to Tropical Asia s.1., or independently from the Neotropics to Tropical Asia s.l.

In spite of this new finding, our study strengthened the scenario of Sundue et al. (2014) of repeated dispersals from the Neotropics to the African-WIO region (Fig. 4): while they inferred at least six such events, our data showed that at least 12 (occurring within the last $20 \mathrm{Ma}$ and including species of 10 distinct genera) must actually be hypothesized to explain the current species richness of the region. This was in line with the observed distribution patterns: indeed, no genus is shared between the African-WIO region and Tropical Asia s.l. (only Ctenopterella and Grammitis were thought to be shared but turned out to be polyphyletic, with distinct lineages in both regions), whereas 11 genera are shared between the African-WIO region and the Neotropics. We do not exclude that the generic affinities between the Neotropics and the African-WIO region could be even greater since two genera were discovered recently in Madagascar, namely Leucotrichum (Rouhan et al., 2012) 
and Moranopteris (this study), which were previously considered endemic to the Neotropics. At the species level, even four species (A. elastica, C. serrulatum, E. sprucei and M. flabelliformis) are shared: this co-occurrence in the Neotropics and WIO may be explained by recent dispersal events ( $<4 \mathrm{Ma}$; and, therefore, insufficient time for geographically disjunct populations to diverge genetically) or by repeated dispersals, causing recurrent gene flow and preventing genetic differentiation.

Another eastward transatlantic migration of grammitid ferns is exemplified by the sister relationships between the Neotropical G. paramicola and G. ebenina, which is endemic to the midSouth Atlantic Ocean island of St. Helena, although this island is geographically closer to Africa (Fig. 4). A similar closer evolutionary relationship between species from St. Helena and the Neotropics has been reported in the genus Elaphoglossum (Vasco et al., 2009).

In contrast to these 12 eastward dispersal events, only one back-dispersal from the African-WIO region to the Neotropics was inferred, in Stenogrammitis (clade-IV; Fig. 4). An additional such westward back-dispersal may have occurred in the Zygophlebia-Enterosora clade, where the African Zygophlebia cf. devoluta was retrieved as basal to a dichotomy of a Neotropical and an African-WIO clades: this pattern suggested either two independent dispersal events from the Neotropics to Africa-WIO, or one migration followed by a back-dispersal. In any case, transatlantic migrations appear highly skewed in their directions, with a predominant eastward direction.

The much higher affinity and closer phylogenetic relationships of grammitid ferns of the WIO with those of the Neotropics, compared to those of Tropical Asia s.l., may be due neither to ecological specificities -in all regions, most species occur in mountain forests- nor to lower dispersal abilities of taxa occurring in Tropical Asia s.1. -most of which have large distribution areas. Therefore, we rather hypothesize a higher potential for dispersal from the Neotropics than from Tropical Asia s.l. due to environmental factors, even if the Neotropics do not seem to be a major area in the biogeographic history of other Malagasy vascular plants: in their broad-scale survey, Buerki et al. 
(2013) identified only two undisputable cases of American ancestry for Malagasy angiosperms (in Haematodendron, Myristicaceae; and Tsoala, Solanaceae). More recently, Smedmark et al. (2014) and Janssens et al. (2016) provided two additional examples of such dispersal from the Neotropics to Africa-WIO in Saldinia and Astiella and closely-related genera, respectively (both Rubiaceae). However, this pattern remains scarce in flowering plants. In contrast, it has been inferred in several fern groups (see Introduction). In some of them (e.g., Parapolystichum and Lastreopsis; Labiak et al., 2014) connexions between the Neotropics and the WIO could be facilitated by overland dispersal events via Antarctica, which were possible until the Late Cretaceous (Buerki et al., 2013; Yoder and Nowak, 2006). However, it cannot be invoked in grammitids, whose stem lineage is younger (here dated to the Eocene at the earliest). Therefore, the most likely hypothesis for the strong link between the Neotropical and the WIO grammitids involves transoceanic LDD. Their highly predominant occurrence in the eastward direction could be due to transport of spores through winds blowing from the west, either surface winds over the Central Atlantic Ocean $\left(10^{\circ} \mathrm{S}-5^{\circ} \mathrm{N}\right.$; even if these are subject to significant year-to-year changes), or the jet streams always blowing from the west and that may extend across the entire Atlantic basin (Renner, 2004). In fact, prevailing westerly trade winds existing at even higher latitudes $\left(30-60^{\circ} \mathrm{S}\right.$ latitude) could also have contributed to skewed dispersals (Munoz et al., 2004), as suggested for many other fern genera with a circumaustral distribution including Madagascar (Labiak et al., 2014; Parris, 2001; Sundue et al., 2010b). Such a very southern trajectory is likely to reach Madagascar and the other WIO islands through the counter clockwise gyre over the South Atlantic Ocean, moving over the ocean south of Africa and arriving in Madagascar, as modelled for spores of Ophioglossum reticulatum (Meza Torres et al., 2015).

4.2.3. At the regional African-WIO scale: Madagascar, rather than Africa, acts as a major source of dispersal 
Many species co-occur in Africa, Madagascar or the other WIO islands: 20 species are shared by at least two of these areas, out of the 51 species recorded in the overall region (Roux, 2009). In agreement with these shared distribution patterns, species that are endemic to one territory were most often retrieved as sister-species to others distributed in nearby areas, showing a high level of dispersal at this regional scale.

Strikingly, we inferred only one possible dispersal event from Africa towards Madagascar and the other WIO islands, which gave rise to clade-III (Fig. 4). In all other cases, the origin of dispersal within the region appeared to be either Madagascar or the other WIO islands. Therefore, Africa does not seem to be a source region for grammitid species in the WIO, contrary to what could be expected based on the Theory of Island Biogeography (MacArthur and Wilson, 1967) and empirical evidence for most of the angiosperms studied (Bacon et al., 2016; Buerki et al., 2013; Janssens et al., 2016; Yoder and Nowak, 2006). Actually, there is a growing body of evidence against the paradigm postulating that continents and islands respectively act as sources and sinks of species diversity (Heaney, 2007), and an increasing awareness of the importance of islands as cradles of diversity themselves: it has been documented for the WIO islands (Agnarsson and Kuntner, 2012; Krüger et al., 2012) and for the Macaronesian islands (Patiño et al., 2015). Although the observed patterns may be overestimated due to missing African species in our study (we included 14 out of 26 African species), grammitid ferns corroborate the latter scenario, and provide another example contradicting the traditional view. This was also suggested by the higher species diversity described from Madagascar compared to continental Africa, which harbour ca. 31 and 26 species, respectively, although Africa is 50 times larger in area. Such a lower taxonomic diversity in Africa compared to Madagascar was also observed in many other fern genera (Kornas, 1993; Roux, 2009). It may be due either to the extinction of lineages after much more severe droughts there than in Madagascar during the Late Miocene and Pleistocene (Aldasoro et al., 2004; Morley, 2000), which led to a decline of African rainforests (Kornas, 1993; Linder et al., 2014; Morley, 2000), or to the 
lack of extensive mountain ranges (Moran, 1995), or most probably to several intricate, both historical and more recent causes (Couvreur, 2015).

From Madagascar and/or the neighbouring islands, dispersal also occurred over larger geographic distances, as evidenced by the colonization of the Subantarctic island of Amsterdam by the genus Stenogrammitis: the phylogeny showed that the Neotropical S. jamesonioides was sister-species to a clade formed by two species, one from Madagascar and Réunion, and the other from Amsterdam. The most likely biogeographic scenario involves a dispersal event from the Neotropics to Madagascar and/or Réunion, later followed by dispersal to Amsterdam (Fig. 4). Whereas Sundue et al. (2014) suggested that circumaustral taxa only originated in Tropical Asia, our results therefore suggest that the WIO area also played a role in the range expansion of grammitids to this temperate area.

\subsubsection{The occurrence of post-dispersal diversification}

In total, at least 13 LDD events may explain the origin of the $>50$ species (including cryptic lineages) sampled in Africa, Madagascar, and other WIO islands. In particular, five LDD gave rise to diversifications counting six to 14 species each. Species diversification probably proceeds at a reduced pace in ferns compared to flowering plants, because of their strong dispersal capacities that slow down genetic differentiation (Gillespie et al., 2012). We actually noticed that diversification occurred in the most ancient lineages, suggesting that the time elapsed since the colonization of a given lineage may be involved in its diversification. Species diversification was probably favoured by the environmental diversity within Madagascar: with its very diverse ecological conditions, the island is known to host spectacular species radiations (Vences et al., 2009; Soulebeau et al., 2015). At the regional scale, the insular system and resulting relative isolation of populations probably also facilitated species diversification, in spite of dispersal. The evolutionary processes involved in such diversification will be investigated in further studies. 


\section{ACKNOWLEDGMENTS}

We thank Drs. B. Senterre, D. Middleton and S. Lindsay for providing leaf material; T. Cheminel and I. Fabre for their help in the lab; and Dr. M. S. Vorontsova and another, anonymous reviewer for their valuable comments on an earlier version of the manuscript. Collecting permits in Madagascar were granted by Madagascar National Parks and the Ministère de l'Environnement, de l'Ecologie et des Forêts. We are also grateful, for field assistance, to CNRE-Madagascar, MBGMadagascar and CNDRS-Comoros (especially Y. Ibrahim). We acknowledge funding from the ATM MNHN 'Emergence des clades, des biotes et des cultures', ATM MNHN 'Taxonomie moléculaire, DNA Barcode \& gestion durable des collections' and the FRB project 'Connaitre pour conserver : le patrimoine naturel caché des Comores'. This project was also supported by the network 'Bibliothèque du Vivant' funded by the CNRS, the MNHN, the INRA and the CEA (Centre National de Séquençage). All molecular work was performed at the BoEM laboratory of the MNHN. 


\section{LITERATURE CITED}

Agnarsson, I., Kuntner, M., 2012. The Generation of a Biodiversity Hotspot: Biogeography and Phylogeography of the Western Indian Ocean Islands, in: Prof. Kesara Anamthawat-Jónsson (Ed.), Current Topics in Phylogenetics and Phylogeography of Terrestrial and Aquatic Systems. Intech, 33-82. doi:10.5772/38958

Aldasoro, J.J., Cabezas, F., Aedo, C., 2004. Diversity and distribution of ferns in sub-Saharan Africa, Madagascar and some islands of the South Atlantic. J. Biogeogr. 31, 1579-1604. doi:10.1111/j.1365-2699.2004.01106.x

Bacon, C.D., Simmons, M.P., Archer, R.H., Zhao, L.-C., Andriantiana, J., 2016. Biogeography of the Malagasy Celastraceae: Multiple independent origins followed by widespread dispersal of genera from Madagascar. Mol. Phylogenet. Evol. 94, 365-382.

doi:10.1016/j.ympev.2015.09.013

Barrington, D.S., Haufler, C.H., Werth, C.R., 1989. Hybridization, reticulation, and species concepts in the ferns. Am. Fern J. 79, 55-64. doi:10.2307/1547160

Beaulieu, J.M., Tank, D.C., Donoghue, M.J., 2013. A Southern Hemisphere origin for campanulid angiosperms, with traces of the break-up of Gondwana. BMC Evol. Biol. 13, 80. doi: $10.1186 / 1471-2148-13-80$

Bickford, D., Lohman, D.J., Sodhi, N.S., Ng, P.K.L., Meier, R., Winker, K., Ingram, K.K., Das, I., 2007. Cryptic species as a window on diversity and conservation. Trends Ecol. Evol. 22, 148155. doi:10.1016/j.tree.2006.11.004

Bishop, L.E., Smith, A.R., 1992. Revision of the Fern Genus Enterosora (Grammitidaceae) in the New World. Syst. Bot. 17, 345. doi:10.2307/2419476

Britton, M.N., Hedderson, T.A., Anthony Verboom, G., 2014. Topography as a driver of cryptic speciation in the high-elevation cape sedge Tetraria triangularis (Boeck.) C. B. Clarke 
(Cyperaceae: Schoeneae). Mol. Phylogenet. Evol. 77, 96-109.

doi:10.1016/j.ympev.2014.03.024

Buerki, S., Devey, D.S., Callmander, M.W., Phillipson, P.B., Forest, F., 2013. Spatio-temporal history of the endemic genera of Madagascar. Bot. J. Linn. Soc. 171, 304-329. doi:10.1111/boj.12008

Callmander, M., 2011. The endemic and non-endemic vascular flora of Madagascar updated. Plant Ecol. Evol. 144, 121-125. doi:10.5091/plecevo.2011.513

Chao, Y.S., Rouhan, G., Amoroso, V.B., Chiou, W.L., 2014. Molecular phylogeny and biogeography of the fern genus Pteris (Pteridaceae). Ann. Bot. 114, 109-124. doi:10.1093/aob/mcu086

Chen, L.-Y., Grimm, G.W., Wang, Q.-F., Renner, S.S., 2015. A phylogeny and biogeographic analysis for the Cape-Pondweed family Aponogetonaceae (Alismatales). Mol. Phylogenet. Evol. 82, 111-117. doi:10.1016/j.ympev.2014.10.007

Couvreur, T.L.P., 2015. Odd man out: why are there fewer plant species in African rain forests? Plant Syst. Evol. 301, 1299-1313. doi:10.1007/s00606-014-1180-z

Dassler, C.L., Farrar, D.R., 2001. Significance of gametophyte form in long-distance colonization by tropical, epiphytic ferns. Brittonia 53, 352-369. doi:10.1007/BF02812705

Drummond, A.J., Suchard, M.A., Xie, D., Rambaut, A., 2012. Bayesian Phylogenetics with BEAUti and the BEAST 1.7. Mol. Biol. Evol. 29, 1969-1973. doi:10.1093/molbev/mss075

Emerick, C.M., Duncan, R.A., 1982. Age progressive volcanism in the Comores Archipelago, western Indian Ocean and implications for Somali plate tectonics. Earth Planet. Sci. Lett. 60, 415-428. doi:10.1016/0012-821X(82)90077-2

Ferreira, M.A.R., Suchard, M.A., 2008. Bayesian analysis of elapsed times in continuous-time Markov chains. Can. J. Stat. 36, 355-368. doi:10.1002/cjs.5550360302

Gernhard, T., 2008. The conditioned reconstructed process. J. Theor. Biol. 253, 769-778. doi:10.1016/j.jtbi.2008.04.005 
Gill, B.A., Kondratieff, B.C., Casner, K.L., Encalada, A.C., Flecker, A.S., Gannon, D.G., Ghalambor, C.K., Guayasamin, J.M., Poff, N.L., Simmons, M.P., Thomas, S.A., Zamudio, K.R., Funk, W.C., 2016. Cryptic species diversity reveals biogeographic support for the "mountain passes are higher in the tropics" hypothesis. Proc. R. Soc. B Biol. Sci. 283, 20160553. doi:10.1098/rspb.2016.0553

Gillespie, R.G., Baldwin, B.G., Waters, J.M., Fraser, C.I., Nikula, R., Roderick, G.K., 2012. Longdistance dispersal: A framework for hypothesis testing. Trends Ecol. Evol. 27, 47-55. doi:10.1016/j.tree.2011.08.009

Goodman, S.M., Benstead, J.P., 2005. Updated estimates of biotic diversity and endemism for Madagascar. Oryx 39, 73-77. doi:10.1017/S0030605305000128

Harper, G.J., Steininger, M.K., Tucker, C.J., Juhn, D., Hawkins, F., 2007. Fifty years of deforestation and forest fragmentation in Madagascar. Environ. Conserv. 34, 325-333. doi:10.1017/S0376892907004262

Haufler, C.H., 2008. Species and Speciation, in: Ranker, T.A., Haufler, C.H. (Eds.), The Biology and Evolution of Ferns and Lycophytes. Cambridge University Press, pp. 303-331.

Heaney, L.R., 2007. Is a new paradigm emerging for oceanic island biogeography? J. Biogeogr. 34, 753-757. doi:10.1111/j.1365-2699.2007.01692.x

Hennequin, S., Hovenkamp, P., Christenhusz, M.J.M., Schneider, H., 2010. Phylogenetics and biogeography of Nephrolepis - a tale of old settlers and young tramps. Bot. J. Linn. Soc. 164, 113-127. doi:10.1111/j.1095-8339.2010.01076.x

Janssen, T., Bystriakova, N., Rakotondrainibe, F., Coomes, D., Labat, J.N., Schneider, H., 2008. Neoendemism in Madagascan scaly tree ferns results from recent, coincident diversification bursts. Evolution, 62:8, 1876-1889. doi:10.1111/j.1558-5646.2008.00408.x

Janssen, T., Kreier, H.-P., Schneider, H., 2007. Origin and diversification of African ferns with special emphasis on Polypodiaceae. Brittonia 59, 159-181. doi:10.1663/0007196X(2007)59[159:OADOAF]2.0.CO;2 
Janssens, S.B., Groeninckx, I., De Block, P.J., Verstraete, B., Smets, E.F., Dessein, S., 2016.

Dispersing towards Madagascar: Biogeography and evolution of the Madagascan endemics of the Spermacoceae tribe (Rubiaceae). Mol. Phylogenet. Evol. 95, 58-66. doi:10.1016/j.ympev.2015.10.024

Katoh, K., Toh, H., 2010. Parallelization of the MAFFT multiple sequence alignment program. Bioinformatics 26, 1899-1900. doi:10.1093/bioinformatics/btq224

Kornas, J., 1993. The Significance of Historical Factors and Ecological Preference in the Distribution of African Pteridophytes. J. Biogeogr. 20, 281-286. doi:10.2307/2845636

Kreier, H.P., Schneider, H., 2006. Phylogeny and biogeography of the staghorn fern genus Platycerium (Polypodiaceae, Polypodiidae). Am. J. Bot. 93, 217-225. doi:10.3732/ajb.93.2.217

Krüger, A., Razafimandimbison, S.G., Bremer, B., 2012. Molecular phylogeny of the tribe Danaideae (Rubiaceae: Rubioideae): Another example of out-of-Madagascar dispersal. Taxon $61,629-636$.

Kuo, L.-Y., Ebihara, A., Shinohara, W., Rouhan, G., Wood, K.R., Wang, C.-N., Chiou, W.-L., 2016. Historical biogeography of the fern genus Deparia (Athyriaceae) and its relation with polyploidy. Mol. Phylogenet. Evol. 104, 123-134. doi:10.1016/j.ympev.2016.08.004

Labiak, P.H., Sundue, M., Rouhan, G., 2010. Molecular phylogeny, character evolution, and biogeography of the grammitid fern genus Lellingeria (Polypodiaceae). Am. J. Bot. 97, 13541364. doi:10.3732/ajb.0900393

Labiak, P.H., Sundue, M., Rouhan, G., Hanks, J.G., Mickel, J.T., Moran, R.C., 2014. Phylogeny and historical biogeography of the lastreopsid ferns (Dryopteridaceae). Am. J. Bot. 101, 1207-1228. doi:10.3732/ajb.1400071

Le Péchon, T., Zhang, L., He, H., Zhou, X.M., Bytebier, B., Gao, X.F., Zhang, L.B., 2016. A wellsampled phylogenetic analysis of the polystichoid ferns (Dryopteridaceae) suggests a complex 
biogeographical history involving both boreotropical migrations and recent transoceanic dispersals. Mol. Phylogenet. Evol. 98, 324-336. doi:10.1016/j.ympev.2016.02.018

Lewis, L.R., Behling, E., Gousse, H., Qian, E., Elphick, C.S., Lamarre, J.-F., Bêty, J., Liebezeit, J., Rozzi, R., Goffinet, B., 2014. First evidence of bryophyte diaspores in the plumage of transequatorial migrant birds. PeerJ 2, e424. doi:10.7717/peerj.424

Linder, H.P., Pennington, T., Schneider, H., 2014. The evolution of African plant diversity. Front. Ecol. Evol. 2, 1-14. doi:10.3389/fevo.2014.00038

Lu, J.M., Wen, J., Lutz, S., Wang, Y.P., Li, D.Z., 2012. Phylogenetic relationships of Chinese Adiantum based on five plastid markers. J. Plant Res. 125, 237-249. doi:10.1007/s10265-011$0441-\mathrm{y}$

MacArthur, R.H., Wilson, E.O., 1967. The theory of island biogeography. Princeton University Press.

Mallet, J., 2007. Hybrid speciation. Nature 446, 279-283. doi:10.1038/nature05706

McDougall, I., Chamalaun, F.H., 1969. Isotopic Dating and Geomagnetic Polarity Studies on Volcanic Rocks from Mauritius, Indian Ocean. Geol. Soc. Am. Bull. 80, 1419. doi:10.1130/0016-7606(1969)80[1419:IDAGPS]2.0.CO;2

Meza Torres, E.I., Cerne, B., Ulke, A.G., Morbelli, M.A., 2015. Distribution of Ophioglossum reticulatum L. in South America. A case of long-distance jump dispersal? Int. J. Biometeorol. 59, 137-150. doi:10.1007/s00484-014-0830-8

Miller, M.A., Pfeiffer, W., Schwartz, T., 2010. Creating the CIPRES Science Gateway for inference of large phylogenetic trees. In: Institute of Electrical and Electronics Engineers (Ed.), Proceedings of the Gateway Computing Environments Workshop (GCE). New York, USA, pp. 1-8. doi:10.1109/GCE.2010.5676129

Moran, R.C., 1995. The importance of mountains to Pteridophytes, with emphasis on Neotropical montane forests, in: Churchill, S.P., Balslev, H., Forero, E., Luteyn, J.L. (Eds.), Biodiversity 
and Conservation of Neotropical Montane Forest. The New York Botanical Garden, Bronx, pp. 359-363.

Moran, R.C., Smith, A.R., 2001. Phytogeographic relationships between neotropical and AfricanMadagascan pteridophytes. Brittonia 53, 304-351. doi:10.1007/BF02812704

Morley, R.J., 2000. Origin and Evolution of Tropical Rain Forests. John Wiley \& Sons.

Munoz, J., Felicísimo, A.M., Cabezas, F., Burgaz, Á.R., Martínez, I., 2004. Wind as a Long-

Distance Dispersal Vehicle in the Southern Hemisphere. Science 304, 1144-1147. doi:10.1126/science. 1095210

Myers, N., Mittermeier, R. a, Mittermeier, C.G., da Fonseca, G.A.B., Kent, J., 2000. Biodiversity hotspsots for conservation priorities. Nature 403, 853-858. doi:10.1038/35002501

Nagalingum, N.S., Schneider, H., Pryer, K.M., 2007. Molecular Phylogenetic Relationships and Morphological Evolution in the Heterosporous Fern Genus Marsilea. Syst. Bot. 32, 16-25. doi:10.1600/036364407780360256

Nougier, J., Cantagrel, J.M., Karche, J.P., 1986. The Comores archipelago in the western Indian Ocean: volcanology, geochronology and geodynamic setting. J. African Earth Sci. 5, 135144. doi:10.1016/0899-5362(86)90003-5

Nylander, J.A.A., 2004. MrModeltest ver. 2.3. Program distributed by author. Evol. Centre, Uppsala Univ.

Parris, B.S., 2012. Ctenopterella gabonensis, a new species of grammitid fern (Polypodiaceae) from Gabon, Africa. Fern Gaz. 19, 89-93.

Parris, B.S., 2009. New genera of Malesian Grammitidacae (Monilophyta). Blumea 54, 217-219. doi:10.3767/000651909X476184

Parris, B.S., 2007. Five new genera and three new species of Grammitidaceae (Filicales) and the reestablishment of Oreogrammitis. Gard. Bull. Singap. 58, 233-274.

Parris, B.S., 2005. Grammitidaceae, in: Beentje, H.J., Ghazanfar, S.A. (Eds.), Flora of Tropical East Africa. Royal Botanic Gardens, Kew. 
Parris, B.S., 2003. The distribution of Grammitidaceae (Filicales) inside and outside Malesia. Telopea 10, 451-466.

Parris, B.S., 2002. New Species and New Combinations in African Grammitidaceae (Filicales). Kew Bull. 57, 423-434. doi:10.2307/4111120

Parris, B.S., 2001. Circum-Antarctic continental distribution patterns in pteridophyte species. Brittonia 53, 270-283. doi:10.1007/BF02812702

Parris, B.S., 1990. Grammitidaceae, in: Kramer, K.., Green, P.S. (Eds.), Pteridophytes and Gymnosperms. Springer, pp. 153-157.

Patiño, J., Carine, M., Mardulyn, P., Devos, N., Mateo, R.G., Gonzalez-Mancebo, J.M., Shaw, A.J., Vanderpoorten, A., 2015. Approximate Bayesian Computation Reveals the Crucial Role of Oceanic Islands for the Assembly of Continental Biodiversity. Syst. Biol. 64, 579-589. doi:10.1093/sysbio/syv013

Perrie, L.R., Parris, B.S., 2012. Chloroplast DNA sequences indicate the grammitid ferns (Polypodiaceae) in New Zealand belong to a single clade, Notogrammitis gen. nov. New Zeal. J. Bot. 50, 457-472. doi:10.1080/0028825X.2012.735247

Pryer, K.M., Schuettpelz, E., Wolf, P.G., Schneider, H., Smith, A.R., Cranfill, R., 2004. Phylogeny and evolution of ferns (monilophytes) with a focus on the early leptosporangiate divergences. Am. J. Bot. 91, 1582-1598. doi:10.3732/ajb.91.10.1582

Rakotondrainibe, F., 2003. Checklist of the pteridophytes of Madagascar, in: Goodman, S., Benstead, J. (Eds.), Natural History of Madagascar. University of Chicago Press, pp. 295313.

Rambaut, A., 2014. FigTree 1.4. 2 software. Institute of Evolutionary Biology, Univ. Edinburgh. Rambaut, A., Drummond, A., 2013. Tracer 1.6. University of Edinburgh, Edinburgh, UK. Ranker, T.A., Smith, A.R., Parris, B.S., Geiger, J.M.O., Haufler, C.H., Straub, S.C.K., Schneider, H., 2004. Phylogeny and evolution of Grammitid ferns (Grammitidaceae): a case of rampant morphological homoplasy. Taxon 53, 415. doi:10.2307/4135619 
Ranker, T.A., Sundue, M.A., Labiak, P., Parris, B.S. Rouhan, G., 2010. New insights into the phylogeny and historical biogeography of the Lellingeria myosuroides clade (Polypodiaceae). PLOS Currents Tree of Life, November 18. Edition 1. doi:10.1371/currents.RRN1197.

Renner, S.S., 2004. Bayesian analysis of combined chloroplast loci, using multiple calibrations, supports the recent arrival of Melastomataceae in Africa and Madagascar. Am. J. Bot. 91, 1427-1435. doi:10.3732/ajb.91.9.1427

Renner, S.S., Strijk, J.S., Strasberg, D., Thébaud, C., 2010. Biogeography of the Monimiaceae (Laurales): a role for East Gondwana and long-distance dispersal, but not West Gondwana. J. Biogeogr. 37, 1227-1238. doi:10.1111/j.1365-2699.2010.02319.x

Ronquist, F., Teslenko, M., van der Mark, P., Ayres, D.L., Darling, A., Höhna, S., Larget, B., Liu, L., Suchard, M.A., Huelsenbeck, J.P., 2012. MrBayes 3.2: efficient Bayesian phylogenetic inference and model choice across a large model space. Syst. Biol. 61, 539-542. doi:10.1093/sysbio/sys029

Rothfels, C.J., Li, F.-W., Sigel, E.M., Huiet, L., Larsson, A., Burge, D.O., Ruhsam, M., Deyholos, M., Soltis, D.E., Stewart, C.N., Shaw, S.W., Pokorny, L., Chen, T., DePamphilis, C., DeGironimo, L., Chen, L., Wei, X., Sun, X., Korall, P., Stevenson, D.W., Graham, S.W., Wong, G.K.-S., Pryer, K.M., 2015. The evolutionary history of ferns inferred from 25 lowcopy nuclear genes. Am. J. Bot. 102, 1-19. doi:10.3732/ajb.1500089

Rouhan, G., Dubuisson, J.-Y., Rakotondrainibe, F., Motley, T.J., Mickel, J.T., Labat, J.N., Moran, R.C., 2004. Molecular phylogeny of the fern genus Elaphoglossum (Elaphoglossaceae) based on chloroplast non-coding DNA sequences: Contributions of species from the Indian Ocean area. Mol. Phylogenet. Evol. 33, 745-763. doi:10.1016/j.ympev.2004.08.006

Rouhan, G., Hanks, J.G., McClelland, D., Moran, R.C., 2007. Preliminary phylogenetic analysis of the fern genus Lomariopsis (Lomariopsidaceae). Brittonia 59, 115-128. doi:10.1663/0007196X(2007)59[115:PPAOTF]2.0.CO;2 
Rouhan, G., Labiak, P.H., Randrianjohany, E., Rakotondrainibe, F., 2012. Not so neotropical after all: the Grammitid fern genus Leucotrichum (Polypodiaceae) is also paleotropical, as revealed by a new species from Madagascar. Syst. Bot. 37, 331-338. doi:10.1600/036364412X635386

Roux, J.P., 2009. Synopsis of the Lycopodiophyta and Pteridophyta of Africa, Madagascar and neighbouring islands. South African National Biodiversity Institute.

Schneider, H., Smith, A.R., Cranfill, R., Hildebrand, T.J., Haufler, C.H., Ranker, T.A., 2004. Unraveling the phylogeny of polygrammoid ferns (Polypodiaceae and Grammitidaceae): exploring aspects of the diversification of epiphytic plants. Mol. Phylogenet. Evol. 31, 10411063. doi:10.1016/j.ympev.2003.09.018

Schuettpelz, E., Pryer, K.M., 2009. Evidence for a Cenozoic radiation of ferns in an angiospermdominated canopy. Proc. Natl. Acad. Sci. 106, 11200-11205. doi:10.1073/pnas.0811136106

Schuettpelz, E., Pryer, K.M., 2007. Fern phylogeny inferred from 400 leptosporangiate species and three plastid genes. Taxon 56, 1037-1050. doi:10.2307/25065903

Sessa, E.B., Testo, W.L., Watkins, J.E., 2016. On the widespread capacity for, and functional significance of, extreme inbreeding in ferns. New Phytol. 211, 1108-1119. doi:10.1111/nph.13985

Seward, D., Grujic, D., Schreurs, G., 2004. An insight into the breakup of Gondwana: identifying events through low-temperature thermochronology from the basement rocks of Madagascar. Tectonics 23, TC3007. doi:10.1029/2003TC001556

Smedmark, J.E.E., Razafimandimbison, S.G., Wikström, N., Bremer, B., 2014. Inferring geographic range evolution of a pantropical tribe in the coffee family (Lasiantheae, Rubiaceae) in the face of topological uncertainty. Mol. Phylogenet. Evol. 70, 182-194. doi:10.1016/j.ympev.2013.09.007

Smith, A.R., 1972. Comparison of Fern and Flowering Plant Distributions with Some Evolutionary Interpretations for Ferns. Biotropica 4, 4-9. doi:10.2307/2989639 
Smith, A.R., Cranfill, R.B., 2002. Intrafamilial Relationships of the Thelypteroid Ferns

(Thelypteridaceae). Am. Fern J. 92, 131. doi:10.1640/0002-

8444(2002)092[0131:IROTTF]2.0.CO;2

Soulebeau, A., Aubriot, X., Gaudeul, M., Rouhan, G., Hennequin, S., Haevermans, T., Dubuisson, J.-Y., Jabbour, F., 2015. The hypothesis of adaptive radiation in evolutionary biology: hard facts about a hazy concept. Org. Divers. Evol. 15, 747-761. doi:10.1007/s13127-015-0220-z

Stamatakis, A., 2014. RAxML version 8: a tool for phylogenetic analysis and post-analysis of large phylogenies. Bioinformatics 30, 1312-1313. doi:10.1093/bioinformatics/btu033

Stokey, A.G., Atkinson, L.R., 1958. The gametophyte of the Grammitidaceae. Phytomorphology 8, $391-403$.

Sugita, N., Ootsuki, R., Fujita, T., Murakami, N., Ueda, K., 2013. Possible spore dispersal of a birdnest fern Asplenium setoi by bonin flying foxes Pteropus pselaphon. Mammal Study 38, 225229. doi:10.3106/041.038.0301

Sundue, M., 2010. A morphological cladistic analysis of Terpsichore (Polypodiaceae). Syst. Bot. 35, 716-729. doi:10.1600/036364410X539808

Sundue, M., Islam, M.B., Ranker, T.A., 2010a. Systematics of Grammitid Ferns (Polypodiaceae): using morphology and plastid sequence data to resolve the circumscriptions of Melpomene and the polyphyletic genera Lellingeria and Terpsichore. Syst. Bot. 35, 701-715. doi:10.1600/036364410X539790

Sundue, M., Parris, B.S., Ranker, T.A., Smith, A.R., Fujimoto, E.L., Zamora-Crosby, D., Morden, C.W., Chiou, W.-L., Chen, C.-W., Rouhan, G., Hirai, R.Y., Prado, J., 2014. Global phylogeny and biogeography of grammitid ferns (Polypodiaceae). Mol. Phylogenet. Evol. 81, 195-206. doi:10.1016/j.ympev.2014.08.017

Sundue, M., Rouhan, G., Moran, R.C., 2010b. Megalastrum (Dryopteridaceae) of the circumaustral region: Chile, Argentina, and Southern Islands of the Atlantic, Pacific, and Indian Oceans. Syst. Bot. 35, 461-475. doi:10.1600/036364410792495935 
Sundue, M.A., Testo, W.L., Ranker, T.A., 2015. Morphological innovation, ecological opportunity, and the radiation of a major vascular epiphyte lineage. Evolution 69, 2482-2495. doi:10.1111/evo.12749

Sylvester, S.P., Sylvester, M.D.P.V., Kessler, M., 2014. The world's highest vascular epiphytes found in the Peruvian Andes. Alp. Bot. 124, 179-185. doi:10.1007/s00035-014-0130-2

Taberlet, P., Gielly, L., Pautou, G., Bouvet, J., 1991. Universal primers for amplification of three non-coding regions of chloroplast DNA. Plant Mol. Biol. 17, 1105-1109. doi:10.1007/BF00037152

Vaidya, G., Lohman, D.J., Meier, R., 2011. SequenceMatrix: concatenation software for the fast assembly of multi-gene datasets with character set and codon information. Cladistics 27, 171180. doi:10.1111/j.1096-0031.2010.00329.x

Vasco, A., Moran, R.C., Rouhan, G., 2009. Circumscription and phylogeny of the Elaphoglossum ciliatum group (E. sect. Lepidoglossa, Dryopteridaceae) based on cpDNA sequences. Taxon 58, 825-834. http://www.jstor.org/stable/27756948

Vences, M., Wollenberg, K.C., Vieites, D.R., Lees, D.C., 2009. Madagascar as a model region of species diversification. Trends Ecol. Evol. 24, 456-465. doi:10.1016/j.tree.2009.03.011

Wang, L., Schneider, H., Wu, Z., He, L., Zhang, X., Xiang, Q., 2012. Indehiscent sporangia enable the accumulation of local fern diversity at the Qinghai-Tibetan Plateau. BMC Evol. Biol. 12, 158. doi:10.1186/1471-2148-12-158

Warren, B.H., Strasberg, D., Bruggemann, J.H., Prys-Jones, R.P., Thébaud, C., 2010. Why does the biota of the Madagascar region have such a strong Asiatic flavour? Cladistics 26, 526-538. doi:10.1111/j.1096-0031.2009.00300.x

Waterhouse, A.M., Procter, J.B., Martin, D.M., Clamp, M., Barton, G.J., 2009. Jalview Version 2--a multiple sequence alignment editor and analysis workbench. Bioinformatics 25, 1189-1191. doi:10.1093/bioinformatics/btp033 
Wei, R., Xiang, Q., Schneider, H., Sundue, M., Kessler, M., Kamau, P.W., Hidayat, A., Zhang, X., 2015. Eurasian origin, boreotropical migration and transoceanic dispersal in the pantropical fern genus Diplazium (Athyriaceae). J. Biogeogr. 45, 1809-1819. doi:10.1111/jbi.12551

Wolf, P., 1997. Evaluation of atpB nucleotide sequences for phylogenetic studies of ferns and other pteridophytes. Am. J. Bot. 84, 1429-1440.

Yoder, A.D., Nowak, M.D., 2006. Has vicariance or dispersal been the predominant biogeographic force in Madagascar? Only time will tell. Annu. Rev. Ecol. Evol. Syst. 37, 405-431. doi:10.1146/annurev.ecolsys.37.091305.110239

Yu, Y., Harris, A.J., Blair, C., He, X., 2015. RASP (Reconstruct Ancestral State in Phylogenies): a tool for historical biogeography. Mol. Phylogenet. Evol. 87, 46-49. doi:10.1016/j.ympev.2015.03.008

Yu, Y., Harris, A.J., He, X., 2010. S-DIVA (Statistical Dispersal-Vicariance Analysis): a tool for inferring biogeographic histories. Mol. Phylogenet. Evol. 56, 848-850. doi:http://dx.doi.org/10.1016/j.ympev.2010.04.011 


\section{TABLES}

Table 1. Grammitid genera occurring in the Western Indian Ocean (WIO, incl. Madagascar) and Africa, based on Roux (2009) updated with more recent genera recognized, and corrected for some distributions.

\begin{tabular}{|c|c|c|c|c|}
\hline Genus & $\begin{array}{l}\text { Number of } \\
\text { species } \\
\text { recorded } \\
\text { worldwide }\end{array}$ & $\begin{array}{l}\text { Number of species } \\
\text { recorded in the } \\
\text { WIO region } \\
\text { [and in Madagascar } \\
\text { only] }\end{array}$ & $\begin{array}{l}\text { Number of } \\
\text { species } \\
\text { recorded in } \\
\text { Africa }\end{array}$ & $\begin{array}{l}\text { Comments (at the worldwide } \\
\text { scale) }\end{array}$ \\
\hline Alansmia & 26 & $\begin{array}{ll}1 & {[1]}\end{array}$ & 1 & \\
\hline Ceradenia & 73 & $\begin{array}{ll}5 & {[2]}\end{array}$ & 2 & \\
\hline Cochlidium & 18 & $1 \quad[1]$ & 1 & 7 \\
\hline Ctenopterella & 24 & $3 \quad[3]$ & 2 & monophyly never tested \\
\hline Enterosora & 11 & $\begin{array}{ll}2 & {[2]}\end{array}$ & 2 & $\begin{array}{l}\text { monophyletic but nested in } \\
\text { Zygophlebia }\end{array}$ \\
\hline Grammitis & 26 & $12[10]$ & 7 & $\begin{array}{l}\text { polyphyletic, and Grammitis s.s. } \\
\text { paraphyletic with respect to } \\
\text { Cochlidium }\end{array}$ \\
\hline Leucotrichum & 6 & $1[1]$ & 0 & \\
\hline Melpomene & 29 & $1<[1]$ & 1 & \\
\hline *Moranopteris & 30 & 0 & 0 & $\begin{array}{l}\text { monophyly to be tested given the } \\
\text { newly discovered species in } \\
\text { Madagascar }\end{array}$ \\
\hline Stenogrammitis & 31 & $\begin{array}{ll}3 & {[3]}\end{array}$ & 7 & \\
\hline Zygophlebia & 20 & $\begin{array}{ll}7 & {[7]}\end{array}$ & 3 & $\begin{array}{l}\text { paraphyletic with respect to } \\
\text { Enterosora }\end{array}$ \\
\hline
\end{tabular}

* Only known from the Neotropics to date, but a new species was recently discovered in Madagascar 
Table 2. PCR primers and thermal cycling conditions; primers used as internal primers for sequencing only are marked with an asterisk $(*)$

\begin{tabular}{|c|c|c|c|c|}
\hline DNA region & Primer name & Literature reference & Primer sequence ( $5^{\prime}$ to $\left.3^{\prime}\right)$ & $\begin{array}{l}\text { Thermal cycling } \\
\text { conditions }\end{array}$ \\
\hline \multirow{8}{*}{$a t p B$} & & Schuettpelz and Pryer, & AAT GTT ACT TGT GAA & \multirow{8}{*}{$\begin{array}{l}5 \min 94^{\circ} \mathrm{C} / 40 \\
\times\left(30 \mathrm{~s} 94^{\circ} \mathrm{C} / 1\right. \\
\min 50^{\circ} \mathrm{C} / 2.5 \\
\left.\min 72^{\circ} \mathrm{C}\right) / 10 \\
\min 72^{\circ} \mathrm{C}\end{array}$} \\
\hline & ESATPB172F & 2007 & GTW CAA CAA T & \\
\hline & & Schuettpelz and Pryer, & ATT CCA AAC WAT TCG & \\
\hline & ESATPE45R & 2007 & ATT WGG AG & \\
\hline & & & ATG GCA GAA TRT TTC & \\
\hline & q OR $1163 F^{*}$ & Wolf, 1997 & CGA GAT RTY A & \\
\hline & & & TTC CTG YAR AGA NCC & \\
\hline & ATPB910R* & Pryer et al., 2004 & CAT TTC TGT & \\
\hline \multirow{7}{*}{$r b c L$} & & Schuettpelz and Pryer, & ATG TCA CCA CAA ACG & \multirow{7}{*}{$\begin{array}{l}5 \min 94^{\circ} \mathrm{C} / 40 \\
\times\left(30 \mathrm{~s} 94^{\circ} \mathrm{C} /\right. \\
45 \mathrm{~s} 50^{\circ} \mathrm{C} / 2.5 \\
\left.\min 72^{\circ} \mathrm{C}\right) / 10 \\
\min 72^{\circ} \mathrm{C}\end{array}$} \\
\hline & ESRBCL1F & 2007 & GAG ACT AAA GC & \\
\hline & ESRBCL1361R & $\begin{array}{l}\text { Schuettpelz and Pryer, } \\
2007\end{array}$ & $\begin{array}{l}\text { TCA GGA CTC CAC TTA } \\
\text { CTA GCT TCA CG }\end{array}$ & \\
\hline & & Schuettpelz and Pryer, & CCA TTY ATG CGT TGG & \\
\hline & ESRBCL628F* & 2007 & AGA GAT CG & \\
\hline & & Schuettpelz and Pryer, & GAA RCG ATC TCT CCA & \\
\hline & ESRBCL654R* & 2007 & ACG CAT & \\
\hline \multirow{5}{*}{$\operatorname{trn} G-\operatorname{trn} R$} & TRNG1F & Nagalinoum et al 2007 & $\begin{array}{l}\text { GCG GGT ATA GTT TAG } \\
\text { TGG TAA }\end{array}$ & \multirow{5}{*}{$\begin{array}{l}5 \min 94^{\circ} \mathrm{C} / 40 \\
\times\left(30 \mathrm{~s} 94^{\circ} \mathrm{C} / 1\right. \\
\min 50^{\circ} \mathrm{C} / 1.5 \\
\left.\min 72^{\circ} \mathrm{C}\right) / 10 \\
\min 72^{\circ} \mathrm{C}\end{array}$} \\
\hline & IRINUIF & Nagalıngum et al., 2007 & TGG TAA & \\
\hline & TRNR22R & Nagalingum et al., 2007 & $\begin{array}{l}\text { CTA TCC ATT AGA CGA } \\
\text { TGG ACG }\end{array}$ & \\
\hline & TRNG43F & Nagalingum et al., 2007 & $\begin{array}{l}\text { TGA TGC GGG TTC GAT } \\
\text { TCC CG }\end{array}$ & \\
\hline & TRN & Nagalingum et al., 2007 & $\begin{array}{l}\text { GCG GGA ATC GAA CCC } \\
\text { GCA TCA }\end{array}$ & \\
\hline \multirow[t]{3}{*}{$\operatorname{trnL}-\operatorname{trn} F$} & & Taberlet et al., 1991 & $\begin{array}{l}\text { ATT TGA ACT GGT GAC } \\
\text { ACG AG }\end{array}$ & \multirow{3}{*}{$\begin{array}{l}5 \min 94^{\circ} \mathrm{C} / 40 \\
\times\left(30 \mathrm{~s} 94^{\circ} \mathrm{C} /\right. \\
30 \mathrm{~s} 50^{\circ} \mathrm{C} / \\
\left.1.5 \min 72^{\circ} \mathrm{C}\right) / \\
10 \min 72^{\circ} \mathrm{C}\end{array}$} \\
\hline & & & & \\
\hline & Fern-1 & Taberlet et al., 1991 & CAG GGR AAC C & \\
\hline \multirow[t]{2}{*}{ rps4-trnS } & rps4-3r.f & Smith and Cranfill, 2002 & $\begin{array}{l}\text { AGT TGT TAG TTG TTG AGT } \\
\text { AT }\end{array}$ & \multirow{2}{*}{$\begin{array}{l}5 \min 94^{\circ} \mathrm{C} / 40 \\
\times\left(30 \mathrm{~s} 94^{\circ} \mathrm{C} /\right. \\
30 \mathrm{~s} 50^{\circ} \mathrm{C} / 45 \mathrm{~s} \\
\left.72^{\circ} \mathrm{C}\right) / 10 \min \\
72^{\circ} \mathrm{C}\end{array}$} \\
\hline & $\operatorname{trnS}-\mathrm{r}$ & Smith and Cranfill, 2002 & TAC CGA GGG TTC GAA TC & \\
\hline
\end{tabular}


Table 3. Statistics on the five separate plastid DNA regions and the combined dataset

\begin{tabular}{lllll} 
DNA region & $\begin{array}{l}\text { Number of } \\
\text { sequences }\end{array}$ & $\begin{array}{l}\text { Aligned length } \\
\text { (in base pairs) }\end{array}$ & $\begin{array}{l}\text { Number of } \\
\text { variable characters }\end{array}$ & $\begin{array}{l}\text { Number of informative } \\
\text { characters }\end{array}$ \\
\hline$a t p B$ & $339(85 \%)$ & 1272 & $436(34 \%)$ & $342(27 \%)$ \\
\hline$r b c L$ & $366(91 \%)$ & 1240 & $482(39 \%)$ & $340(27 \%)$ \\
\hline$r p s 4-t r n S$ & $307(76 \%)$ & 767 & $505(66 \%)$ & $422(55 \%)$ \\
\hline$t r n G-t r n R$ & $271(67 \%)$ & 1671 & $937(56 \%)$ & $747(45 \%)$ \\
\hline$t r n L-t r n F$ & $360(90 \%)$ & 643 & $431(67 \%)$ & $316(49 \%)$ \\
\hline Combined dataset & $401(100 \%)$ & 5593 & $2791(50 \%)$ & $2167(39 \%)$
\end{tabular}


Table 4. Taxonomic issues at the species level for African and WIO grammitid fern taxa, raised by the molecular phylogenetic results; taxonomic novelties accommodating these results are suggested whenever possible. Non-monophyletic species are indicated in color (same colors as in Fig. 3). For some species, several issues emerged and were distinguished by i/ and ii/, while the distinct lineages of non-monophyletic species were distinguished by a/ and b/.

\begin{tabular}{|c|c|c|c|c|}
\hline Species & Figure & Monophyletic & Taxonomic issues & Taxonomic novelties suggested \\
\hline Ctenopterella parvula & $\begin{array}{l}\text { Fig. } 2 \\
\text { Fig. } 3 \text {, clade- } \\
3\end{array}$ & yes & $\begin{array}{l}\text { belongs to clade- } 3 \text {, a newly recovered } \\
\text { clade for grammitids }\end{array}$ & $\begin{array}{l}\text { should possibly be placed in a new genus if } \\
\text { the type species of the genus ( } C \text {. blechnoides) } \\
\text { belongs to a distinct clade }\end{array}$ \\
\hline Enterosora sprucei & $\begin{array}{l}\text { Fig. } 2 \\
\text { Fig. } 3 \text {, clade- } \\
1\end{array}$ & no & $\begin{array}{l}\text { i/ belongs to a newly recovered clade ( } E \text {. } \\
\text { sprucei/E.parietina) for grammitids } \\
\text { ii/ paraphyletic with respect to } E \text {. } \\
\text { parietina- Sundue } 3097\end{array}$ & $\begin{array}{l}\text { i/ E.sprucei/E.parietina should possibly be } \\
\text { placed in a new genus if the type species of } \\
\text { the genus (E. campbellii) belongs to a distinct } \\
\text { clade } \\
\text { ii/ to be synonymized with E. parietina } \\
\text { (earliest species name) }\end{array}$ \\
\hline $\begin{array}{l}\text { Grammitis } \\
\text { cryptophlebia }\end{array}$ & \multirow{3}{*}{$\begin{array}{l}\text { Fig. 3, clade- } \\
1\end{array}$} & no & cryptic species, diphyletic & to be further investigated \\
\hline Grammitis ebenina & & no & $\begin{array}{l}\text { cryptic species, diphyletic: } \\
\text { a/ St-Helena } \\
\text { b/ Madagascar }\end{array}$ & $\begin{array}{l}\text { a/ remains as G. ebenina (type specimen from } \\
\text { St Helena) } \\
\text { b/ } 1 \text { new species, endemic to Madagascar }\end{array}$ \\
\hline $\begin{array}{l}\text { Grammitis } \\
\text { kyimbilensis }\end{array}$ & & no & $\begin{array}{l}\text { cryptic species, diphyletic } \\
\text { a/ Tanzania } \\
\text { b/ Madagascar }\end{array}$ & $\begin{array}{l}\text { a/ remains as G. kyimbilensis (type specimen } \\
\text { from Tanzania) } \\
\text { b/ } 1 \text { new species, endemic to Madagascar }\end{array}$ \\
\hline
\end{tabular}


ACCEPTED MANUSCRIPT

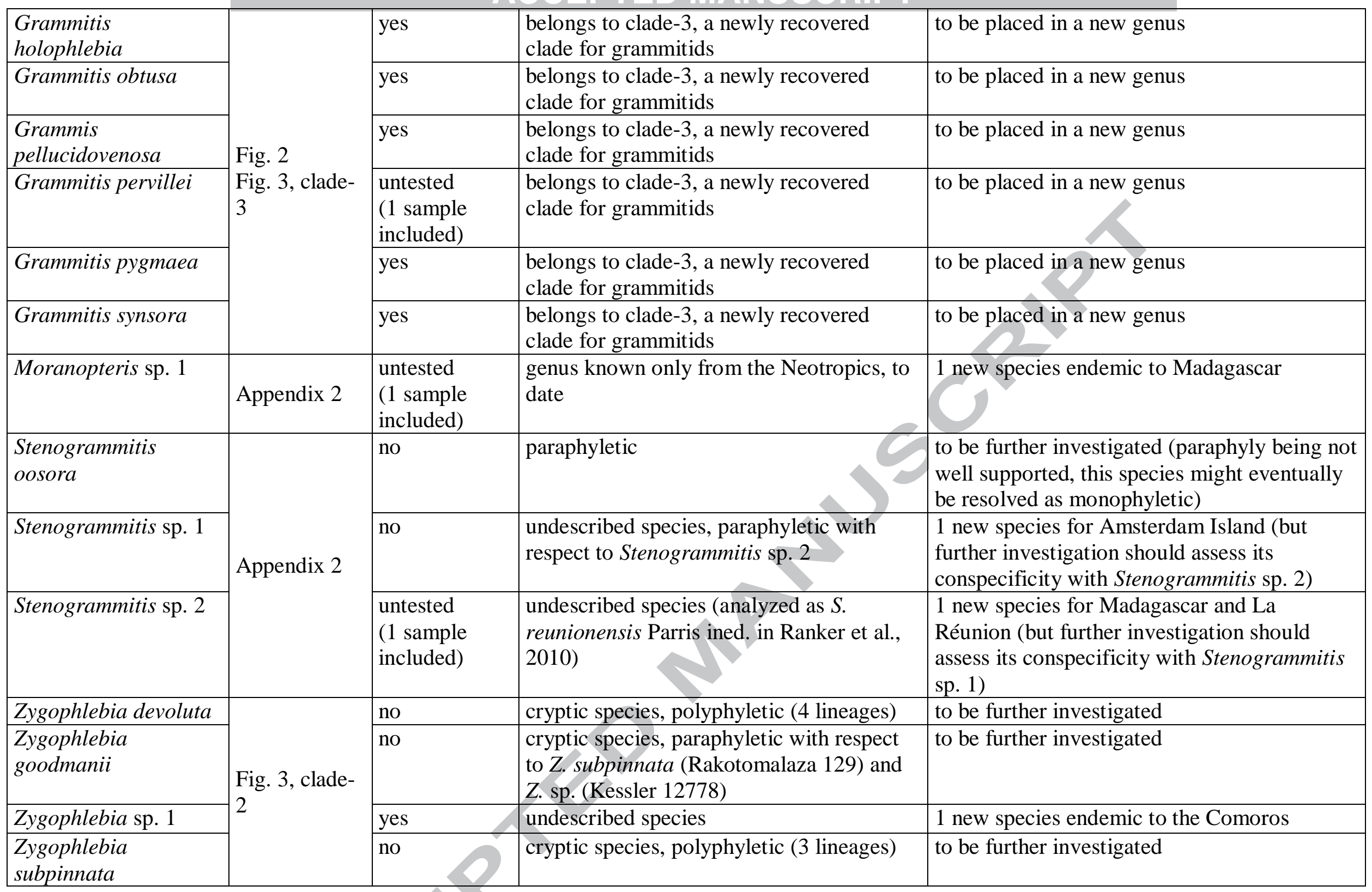




\section{FIGURES}

Fig.1 - Morphology and habit of the 11 genera distributed in Madagascar: (A) Alansmia elastica (Rouhan et al. 1138); (B) Ceradenia deltodon (Rouhan et al. 1350); (C) Ctenopterella zenkeri (Rouhan et al. 1347); (D) Enterosora sprucei (Rouhan et al. 1227); (E) Grammitis copelandii (Rouhan et al. 1190); (F) Leucotrichum madagascariense (Rakotondrainibe 6957); (G) Moranopteris sp. 1 (Bauret et al. 107); (H) Stenogrammitis hildebrandtii (Rouhan et al. 1375); (I) Melpomene flabelliformis (Bauret et al. 105); (J) Zygophlebia goodmanii (Rouhan et al. 1382); (K) Cochilidum serrulatum (Bauret et al. 7). Photos: G. Rouhan; except G, I, K: L. Bauret.

Fig. 2 - Majority rule consensus phylogram of grammitids recovered from the BI based on the combined dataset ( $a t p B, r b c L, \operatorname{trn} G$-trnR, trnL-trnF and $r p s 4-t r n S$ ), and figured as a summary phylogeny (infrageneric branches are shown in Appendix 2). Generic lineages are represented by triangles (whose heights are proportional to the numbers of samples included), with names of genera preceded by colored squares figuring their geographic distribution (see map) and followed by (number of species analyzed / number of samples included). Non-monophyletic genera are indicated in bold and their names are followed by symbols showing the distinct lineages of a given genus. The three grey-filled triangles are the three newly evidenced clades, and circled numbers (1 to 3) correspond to clades detailed in Figure 3. Unless mentioned next to the nodes, support values were $\mathrm{BS} \geq 95$ and $\mathrm{PP} \geq 0.95$.

Fig. 3 - Detailed phylograms of clades 1 to 3 . Unless mentioned next to the nodes, support values were $\mathrm{BS} \geq 95$ and $\mathrm{PP} \geq 0.95$ (also highlighted by thick branches). Non-monophyletic species are indicated in bold and by one color per species. Vouchers are indicated when several samples of the same species were sequenced, and localities specified are discussed in the text. 
Fig. 4 -Molecular dating estimates (represented on the maximum clade credibility tree) and ancestral areas reconstruction inferred by BEAST and S-DIVA, respectively, on the reduced ingroup sampling of 149 samples. The four calibrated nodes are surrounded by squares and horizontal blue bars correspond to $95 \%$ HPD intervals of the median divergence dates. Next to terminals, colored squares depict geographic distribution considering nine areas: (A) Madagascar; (B) Mascarenes, Comoros and Seychelles; (C) Africa; (D) Neotropics; (E) Tropical Asia s.l.; (F) Pacific Ocean islands; (G) Temperate circumaustral region; (H) South Atlantic Islands; (I) North America. At each node, colored pies represent the inferred ancestral distribution. A two-color but one-block pie stands for a distribution covering two areas, inferred with probability $p=1$; a twoblock pie indicates that two alternative distributions were inferred, with $p=0.5$ each (see the graphic legend). Black triangles on branches indicate the 13 LDD events inferred from other areas than A, B and C to at least one of them. Clades I to V are those that diversified in Africa and WIO. Inferred dispersals are reported on the map, with line thickness proportional to the relative number of events (see Discussion). 


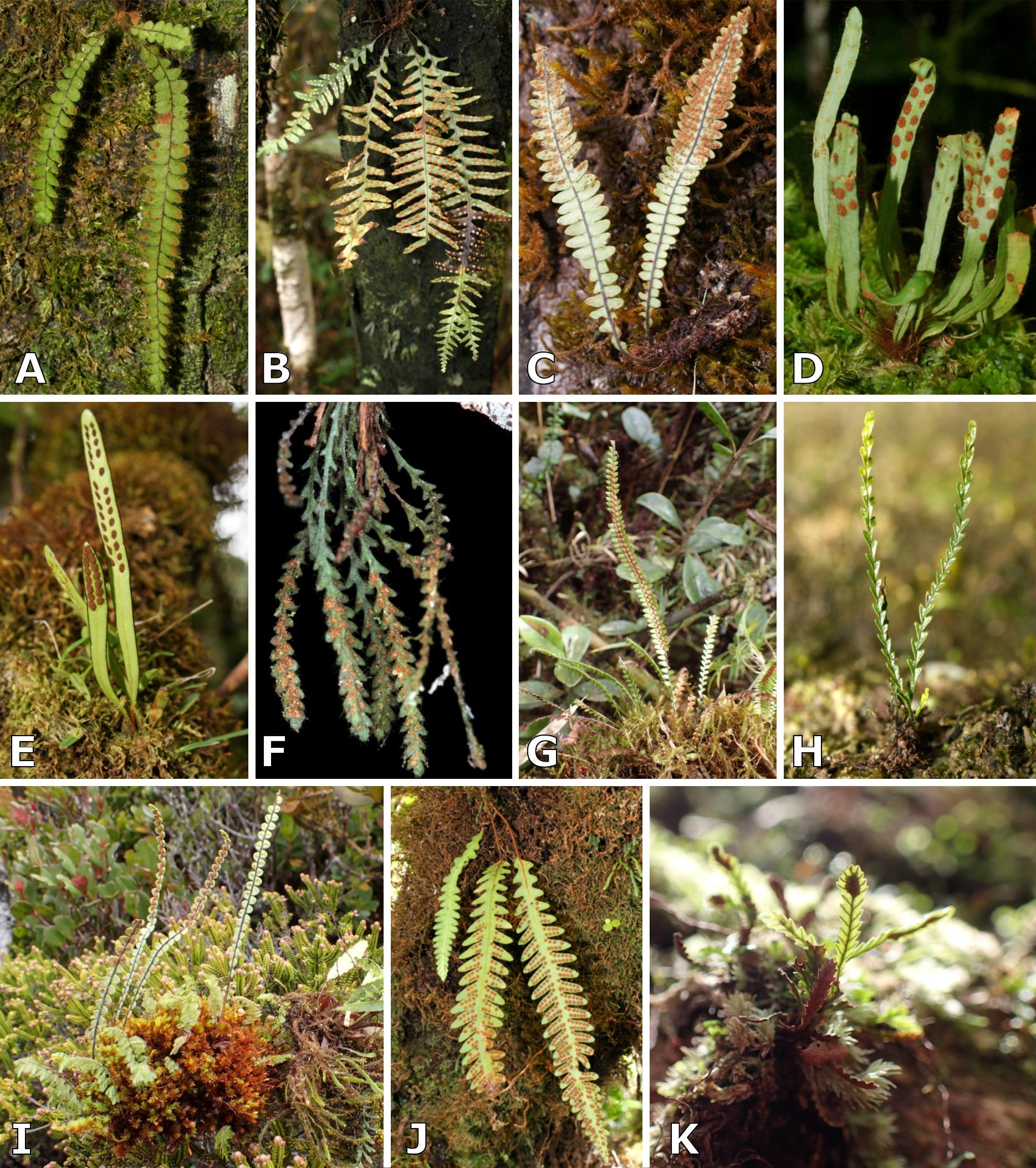




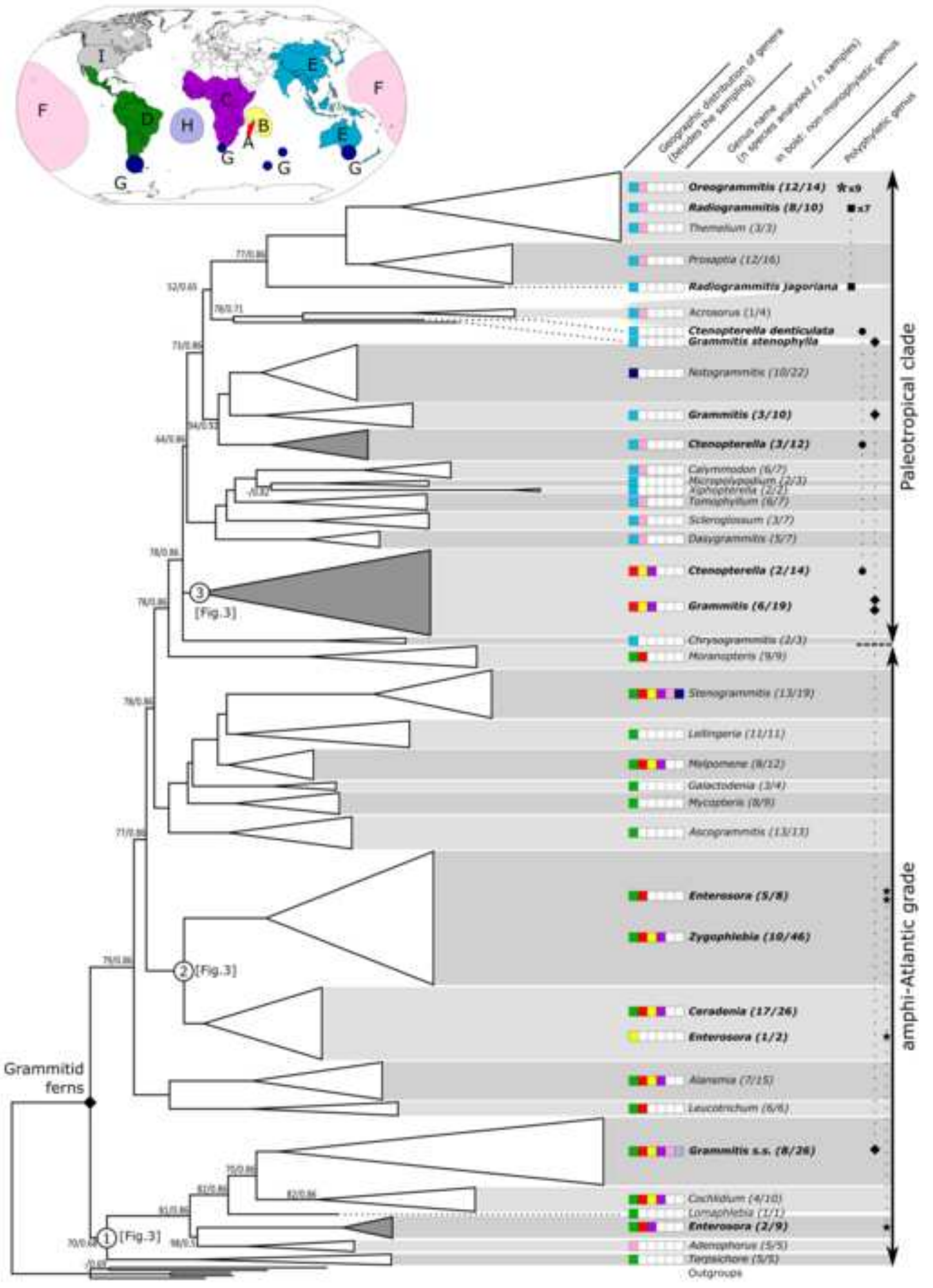




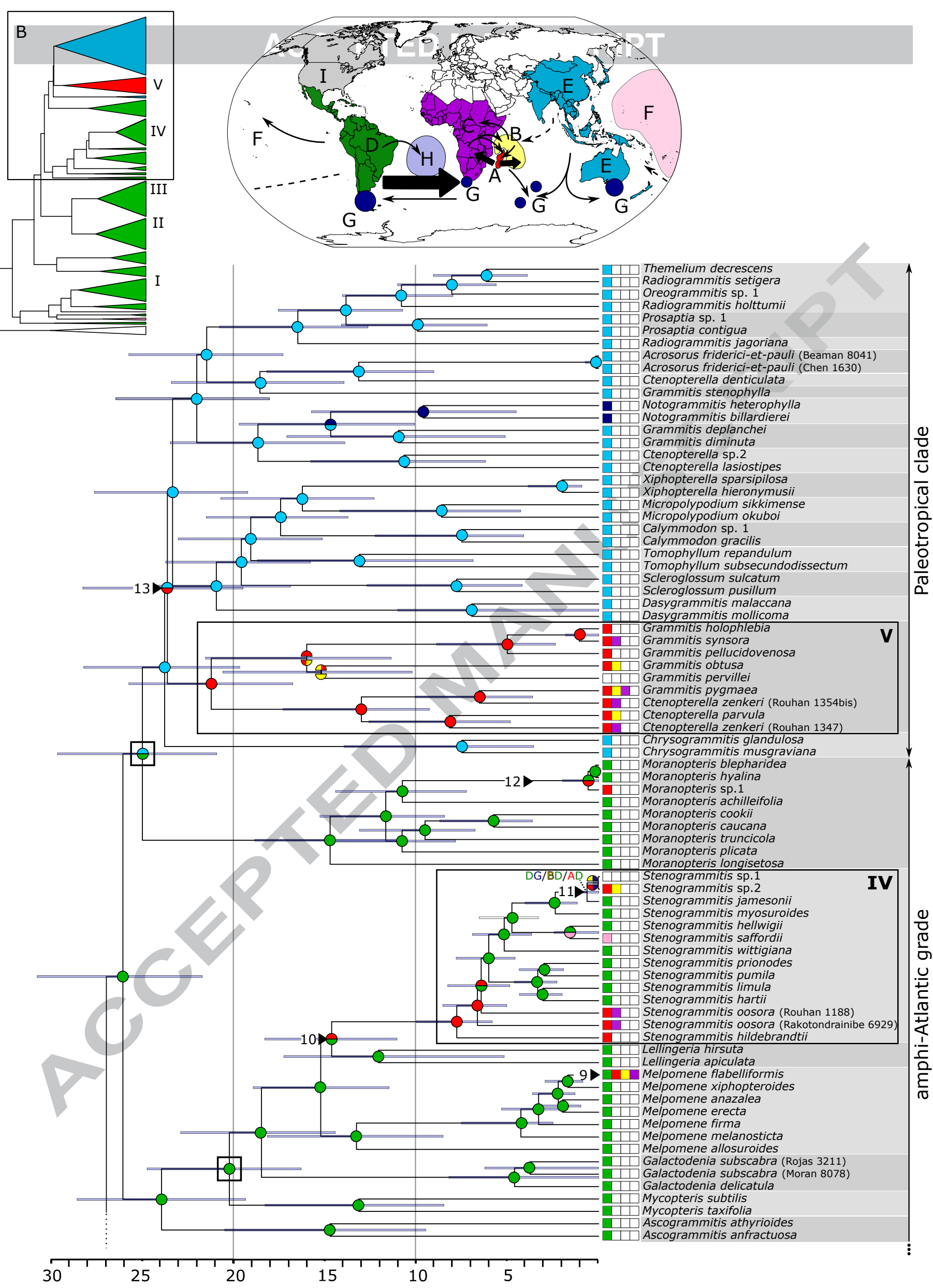

Plio. Ple.
Grey ancestral area, $\mathrm{p}=1$

$\ominus$ Grey+white ancestral area, $p=1$

$\triangle$ White+grey ancestral area, $p=0.5$

Black+grey ancestral area, $p=0.5$ 


\section{SUPPLEMENTARY MATERIAL}

\section{Appendix 1}

Vouchers and GenBank accession numbers. Newly sequenced samples are in bold. Herbarium acronyms follow the Index Herbarium (http://sweetgum.nybg.org/ih/, accessed 19 August 2016).

\section{Appendix 2}

Fully detailed majority rule consensus phylogram of grammitids recovered from the BI based on the combined dataset (atpB, rbcL, trnG-trnR, trnL-trnF and $r p s 4-t r n S)$. Unless mentioned next to the nodes, support values were $\mathrm{BS} \geq 95$ and $\mathrm{PP} \geq 0.95$. Non-monophyletic species are highlighted in bold and by one color per species. Vouchers are indicated when several samples were included for the same species. Genera names are on the right, followed by (number of species analyzed / number of samples included), as in Fig. 1. 


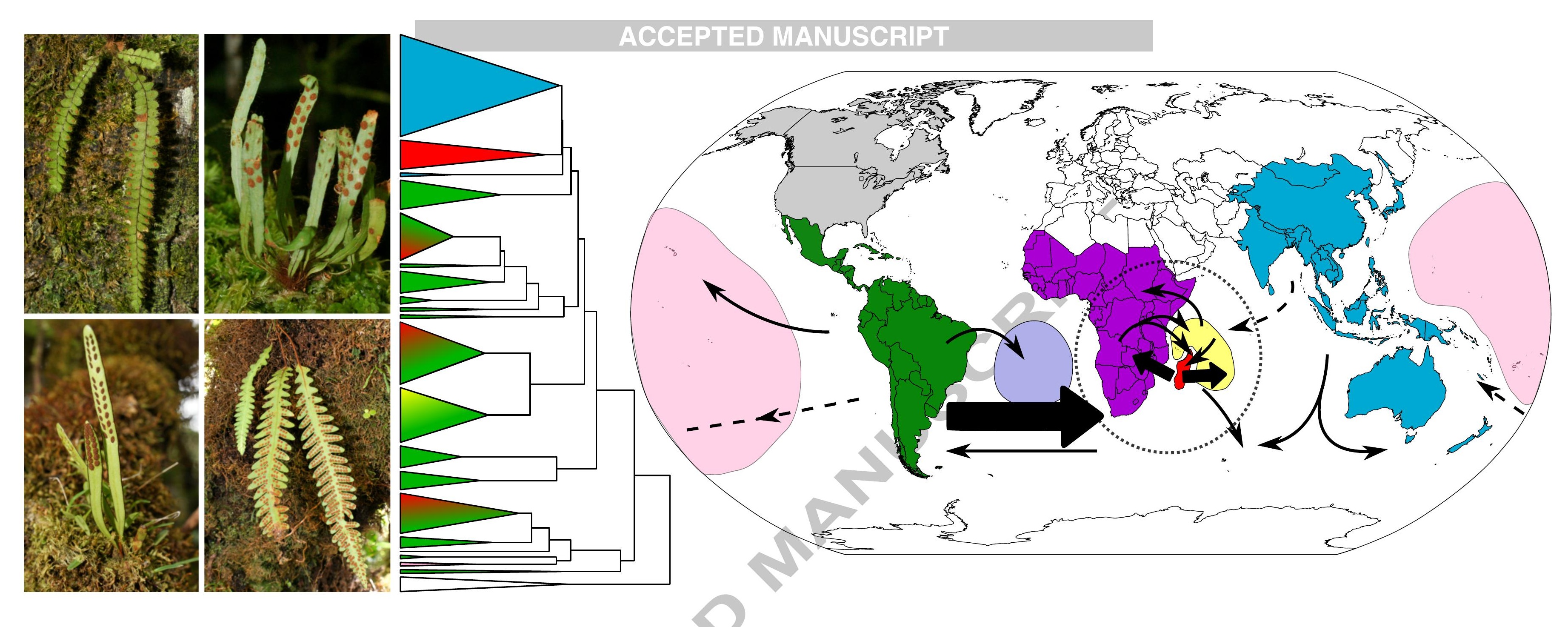

